\title{
REKONSTRUKSI EPISTIMOLOGI ILMU USHUL FIKIH BERBASIS ILMU SEJARAH
}

\author{
Badruzaman \\ Universitas Islam Negeri RadenIntan Lampung \\ badruzamanbanten@gmail.com
}

\author{
Ade Musofa \\ Universitas Mathla'ul Anwar, Banten \\ ademusofa@gmail.com
}

\begin{abstract}
This research focuses on the study of Hasan Hanafi's thoughts on "Reconstruction of the History of Islamic Jurisprudence Epistemology". From the results of the study found several findings; 1). Hasan Hanafi is a figure who is very concerned about efforts to revive the spirit and spirit (revitalization) of Usul Figh Science by using a historical approach. According to him, historical and buman dimensions are important factors in order to approach the conceptions and methodology of Usul Figh. Actually the historical and human dimensions are contained in the standard methodology of Usul Figh but this historical dimension is gradually "extinct" and is independent of Usul Fiqh when the process of developing this Science takes place and manifests in the process of the development of this science. So in fact according to Hasan Hanafi, the historical dimension is essentially manifested in all the elements of Usul Fiqh, namely in 'fairy syar'iyah, thuruq al istinbat and al abkam al syariiyah. This historical dimension is represented by Hasan Hanafi with two keywords, namely "bistory" and "man"; 2). Hasan Hanafi is a person who cares about the existence of the Science of Usul Figh, in that context he said the importance of revitalizing the methodology of Usul Fiqh. Revitalization in Hasan Hanafi's thoughts is an effort to make updates and adjustments to the methodology of Usul Fiqh based on the conditions of social settings and the reality of bumanity and the developing sciences, but this effort starts with the traditions and treasures of the methodology of Usul Fiqh which was built by previous scholars. With this effort, it is hoped that the renewal of the methodology of Usul Figh on one hand can solve contemporary legal
\end{abstract}


problems that are increasingly complicated, but on the other hand it is not uprooted from the roots and genealogical methodology of Usul Fiqh; 3). The thought of Usul Figh Hasan Hanafi is very relevant to the efforts to re-actualize Islamic law. This is due to a deep "stagnation" in the thought of Usul Fiqh so that in reality the Science of Usul Fiqh has been frozen. The significance of the thought of Usul Fiqh Hasan Hanafi lies in the effort to revive the spirit and vital vitality of this Science by using a historical approach. Namely that that the buman dimension and history become one thing that must be involved in the process of judging the law; 4). The historical thinking of Usul Fiqh Hasan Hanafi which is covered in human and historical dimensions actually has roots in Hasan Hanafi's thoughts and projects on al Turas wa al Tajdid (Tradition and Renewal). Because the loss of the human dimension and history in the traditions and treasures of Muslim thought is a central problem that is the cause of the zero progression in the traditions and actions of Muslims.

\section{Abstrak}

Penelitian ini memfokuskan pada kajian pemikiran Hasan Hanafi tentang "Rekonstruksi Epistimologi Ilmu Ushul Fikih Berbasis Ilmu Sejarab". Dari hasil kajian ditemukan beberapa temuan; 1). Hasan Hanafi adalah tokoh yang sangat concern terhadap upaya mengidupkan kembali rub dan spirit (revitalisasi) Ilmu Ushul Figh dengan menggunakan pendekatan historis. Menurutnya dimensi sejarah dan manusia menjadi faktor yang penting dalam rangka mendekati konsepsi-konsepsi dan metodologi Ushul Fiqh. Sebenarnya dimensi sejarah dan manusia tersebut terdapat dalam metodologi Ushul Figh yang baku namun dimensi sejarah ini lama-lama "punah" dan terlepas dari Ushul Fiqh ketika proses pembangunan Ilmu ini berlangsung dan mewujud dalam proses perkembangan ilmu ini. Sehingga sesunggubnya menurut Hasan Hanafi, dimensi sejarah pada hakekatnya mewujud dalam selurub unsur Ushul Fiqh, yaitu dalam 'adillah syar'iyah, thuruq al istinbat dan al abkam al syar'iiyah. Dimensi sejarah ini direpresentasikan oleh Hasan Hanafi dengan kedua kata kunci, yaitu "sejarab" dan "manusia"; 2). Hasan Hanafi adalab orang yang peduli terhadap keberadaan Ilmu Ushul Figh, dalam rangka itu dia mengatakan akan pentingnya upaya revitalisasi metodologi Ushul Fiqh. Revitalisasi dalam pemikiran Hasan Hanafi adalab upaya melakukan pembaharuan dan penyesuaian terhadap metodologi Ushul Fiqh berdasar kondisi setting sosial dan realitas kemanusiaan serta ilmu-ilmu yang berkembang, namun usaba ini bertitik tolak pada tradisi dan khazanah metodologi Ushul Figh yang dibangun oleh ulama terdabulu. Dengan usaba demikian maka diharapkan pembaharuan metodologi Ushul Fiqh pada satu sisi dapat memecabkan problem bukum kontemporer yang semakin complicated, namun pada sisi yang lain tidak tercerabut dari akar dan genealogi metodologi Ushul Fiqh; 3). Pemikiran Ushul Fiqh Hasan Hanafi sangat relevan terhadap upaya reaktualisasi hukum Islam. Hal ini dikarenakan terjadi sebuah "kejumudan" yang mendalam dalam 
pemikiran Ushul Fiqh sehingga dalam realitas yang sebenarnya Imu Ushul Fiqh telah terjadi proses pembekuan. Signifikansi pemikiran Ushul Fiqh Hasan Hanafi terletak pada upaya memghidupkan kembali spirit dan elan vital Ilmu ini dengan meggunakan pendekatan historis. Yaitu bahwa babwa dimensi manusia dan sejarah menjadi satu hal yang harus dilibatkan dalam proses istimbath bukum; 4). Pemikiran historis Usbul Fiqh Hasan Hanafi yang tercover dalam dimensi manusia dan sejarah sesunggubnya mempunyai akar dari pemikiran dan proyek Hasan Hanafi tentang al Turas wa al Tajdid (Tradisi dan Pembaharuan). Karena bilangnya dimensi manusia dan sejarah dalam tradisi dan khazanah pemikiran umat Islam merupakan persoalan pokok yang menjadi sebab dari tidak nibilnya progresifitas dalam tradisi dan tindakan umat Islam.

Keywords: Reconstruction, Epistemology, Usul Fikih, Hasan Hanafi, History.

\section{A. Pendahuluan}

Hukum Islam merupakan salah satu pilar yang sangat vital dan urgen dalam agama Islam. Tidak bisa dipungkiri lagi bahwa hampir di semua lini kehidupan umat Islam, baik dalam lingkungan ibadah maupun muamalah, kehidupan privat maupun publik diatur dan dikondisikan sedemikian rupa oleh hukum Islam. ${ }^{1}$ Itulah mengapa banyak pakar yang menyebut hukum Islam sebagai inti (core) dari ajaran Islam, karena hukum Islam hampir terwujud dalam seluruh aspek kehidupan manusia dan memegang peranan yang penting dalam kehidupan seorang muslim. Selain itu tidak mungkin dapat memahami kebudayaan, sejarah, kondisi sosial dan tata masyarakat Islam tanpa melalui hukum Islam $^{2}$ karena ia adalah entitas terpenting dari agama Islam dalam membentuk tata sosial Islam (Islamic social order).

Berbicara lebih mendalam tentang substansi hukum Islam atau dalam bahasa Islamnya figh atau ada juga ada yang menyebutnya

${ }^{1}$ Menurut Fathi Usman dalam al Fikri al-Qanun al Islamy : Bain al Ushul wa Al syariah,h. 25-26. Hukum Islam terbagi menjadi tujuh lingkungan hukum, yaitu : Pertama, Abkam Al-Abwal alSyakhsiyah (Hukum keluarga) Kedua Abkam Al Jinayah (Hukum Pidana) Ketiga, Abkam Al Murafa'at (Hukum Acara Perdata, Acara Pidana dan PTUN) Keempat Abkam Al-Dusturiyah. Kelima Abkam AlDauliyah (hukum politik internasional ), Keenam Ahkam al Iqtishadiyah wa al maliyah ( hukum ekonomi dan keuangan) dan Ketujuh Al Abkam Al maliyah (Hukum kebendaan).

${ }^{2}$ Lihat Joseph Schacht, An Intoduction to Islamic Law, (London : Oxford At The Clarendon Press, 1971), h. 1. 
sebagai Syari'ah ${ }^{3}$ maka sesungguhnya sangat jauh berbeda dengan konsepsi hukum dalam artian hukum Positif. Ahmad Hasan misalnya mencatat bahwa hukum Islam bukan hanya berarti hukum dalam artian yang selama ini populer, yang melulu berkaitan dengan persoalan-persoalan di pengadilan (purely legal), tetapi lebih luas dari itu hukum Islam mengatur persoalan etika, agama, politik, ekonomi, dan sosial. Ada perbedaan yang cukup signifikan antara hukum dalam pengertian hukum modern dan hukum Islam. Hukum dalam pengertian hukum modern adalah sebuah aturan-aturan tertentu yang mengatur persoalan sosial, ekonomi dan politik dari sebuah negara yang dibuat oleh sebuah otoritas yang kompeten dan ditegakkan dengan sanksi oleh negara.

Adapun aturan-aturan moral dan perilaku individu tidak diatur oleh negara, meskipun sesungguhnya ada dalam aturan adat sitiadat, ritus dan kebiasaan masyarakat. Sedangkan hukum Islam meliputi aturan-aturan perilaku manusia dalam semua lini kehidupan manusia yang menjamin kebahagiaan hidup manusia, baik di dunia maupun di akhirat. Penegakan terhadap hukum ini menjadi kewajiban dari sebuah negara. ${ }^{4}$

Sebagai fungsi kontrol sosial, hukum dituntut untuk terusmenerus melakukan akselerasi, merespon dan memberi solusi terhadap persoalan-persoalan kemanusiaan yang ada yang muncul dalam ruang historis tertentu. Problematika dan kasus-kasus hukum selalu saja muncul dan berkembang sesuai dengan perkembangan manusia itu sendiri, demikian pula sesungguhnya yang terjadi dalam hukum Islam. Hukum Islam akan benar-benar dapat memainkan peran dan fungsinya dengan baik jika mampu mengikuti perkembangan hukum manusia yang senantiasa dinamis dan berkembang.

3Biasanya istilah "fiqh" difahami sebagai hukum dan aturan Tuhan yang sudah melalui proses penafsiran secara empiris. Sedangkan "syari'ah" difahami sebagai ketetapan Tuhan yang masih normativ dan terdapat dalam nash-nash syari'ah, baik Al Qur'an maupun Sunah. Perbedaan dan penjelasan yang lebih lengkap tentang hal ini baca dalam Qordy Azizy, Eklektisisme Hukum :Kompetisi Antara Hukum Islam dan Hukum Umum, (Yogyakarta : Gama Media, 2002), h. 47-57

${ }^{4}$ Ahmad Hasan, The Early Development of Islamic Jurisprudence, (Karachi : Kitab Bavan, 1989), h. VII-VIII. 
Apalagi hukum Islam yang secara substansi hukum meliputi seluruh kehidupan manusia, dengan sendirinya dituntut untuk lebih dapat melakukan adaptasi dan transformasi terhadap kondisi sosial masyarakat. Dalam konteks inilah dibutuhkan sebuah upaya reaktualisasi terhadap hukum Islam, yaitu sebuah upaya untuk menggali sevara intensif atas apa yang diyakini sebagai standarstandar Islam yang benar agar dapat dipedomani dalam beradaptasi dengan konteks masyarakat kini yang terus berubah. ${ }^{5}$ Upaya reaktualisasi hukum Islam akan berjalan dengan baik jika berpangkal pada kerangka teoritis (theorytical frame) atau epistemologi hukum Islam. ${ }^{6}$ Dalam konteks ini maka Ilmu Ushul Fiqh sebagai epistemologi hukum Islam dituntut untuk senantiasa sensitif terhadap perubahan masyarakat. Karena ia seperti sebuah kotak pandora harus mampu memproduksi hukum-hukum Islam yang relevan dan solutif bagi persoalan kemanusiaan sepanjang zaman. Dalam semangat inilah seorang pemikir muslim Sudan, Hasan al-Turaby mempunyai kegundahan yang luar biasa terhadap keberadaan Ilmu Ushul Fiqh, ia berpendapat bahwa Ilmu Ushul Figh sudah seharusnya dilakukan pembaharuan yang fundamental dalam rangka membingkai persoalan hukum yang semakin dinamis dari waktu ke waktu. ${ }^{7}$

Sebagai metode pemahaman (ta'wil), pengeluaran (istinbat) dan penetapan (isbat) hukum Islam, Ilmu Ushul Fiqh dalam rentang sejarah keberadaannya telah mengalami evolusi dan perkembangan metodologis yang cukup dinamis. Sejak pertama kali terbentuknya secara formal yaitu ketika tersusunya kitab Al-Risalah karya Imam

5Istilah "reaktualisasi hukum Islam" menjadi sesuatu yang menghentak dan populer di kalangan umat Islam Indonesia setelah menteri Agama pada waktu itu, Munawir Sadzali menggulirkan dan mensosialisasikannya kepada masyarakat. Terutama berkaitan dengan kasus hukum kewarisan. Selanjutnya baca Mualim dan Yusdani, Konfigurasi Pemikiran Hukum Islam, (Yogyakarta, UII Press), h. 19

${ }^{6}$ Bandingkan dengan M. Amin Abdullah, Paradigma Alternatif Pengembangan Ushul Figh dan Dampaknya pada Figh Kontemporer dalam "Madzhab Jogja : Membangun Ilmu Ushul FiqhBerparadigma Kontemporer", Ainurrofiq (ed), (Yogyakarta : Arruz, 2003), h. 121.

${ }^{7}$ Selanjutnya Baca Hasan al Turaby, Tajdid al Fiker al Islamy, Ter Abd. Kharis dan Za'im Am, "Fiqh Demokratis : Dari Tardisionalisme Kolektif Menuju Modernisme Populis”, (Arasy, Cet I, 2003), h. 50-71 
Syafi'i. ${ }^{8}$ Walaupun sebenarnya secara substansial sudah ada masa Nabi dan Sahabat-sampai saat ini, Ilmu Ushul Fiqh telah mengalami perkembangan yang sangat monumental. Itu ditunjukkan dengan tersusunnya beberapa karya besar para Ushuliyyun dalam sejarah Islam. Nama-nama seperti Imam Syafi'I, Imam Ghazali, Al-Razy, AlJuwaini, Ibnu Qayim Al-Jauziyah dan imam Al-Syatibi adalah tokohtokoh besar dalam sejarah Islam yang memberi perhatian lebih terhadap disiplin Ilmu Ushul Fiqh. ${ }^{9}$ Ini mengindikasikan bahwa disiplin Ilmu Ushul Fiqh menjadi perhatian yang cukup serius di kalangan umat Islam dan pakar hukum Islam, bahkan dapat dikatakan bahwa Ushul Fiqh adalah arus utama (main stream) yang menjadi hulu dari cabang-cabang pemikiran Islam yang ada. Sebenarnya kalau kita telaah lebih mendalam Ilmu Ushul Fiqh bukanlah metodologi baku bagi hukum Islam saja tetapi merupakan metodologi bagi pemikiran keislaman secara umum. Ushul Fiqh merupakan sebuah metodologi yang monumental dan sangat penting yang ditemukan oleh pakar pemikir Islam yang tidak dimiliki oleh umat lain. Dengan demikian sangat dapat dimengerti bila dikatakan bahwa kemunduran yang dialami oleh fiqh Islam dewasa ini diduga kuat juga disebabkan kurang relevannya perangkat teoritik Ilmu Ushul Fiqh dalam memecahkan problem kontemporer. ${ }^{10}$

Dalam perkembangan selanjutnya Ilmu Ushul Fiqh mengalami, apa yang disebut oleh Muhammad Arkoun sebagai "taqdis al afkar al-Islamiy" atau pensakralan terhadap ilmu-ilmu keislaman. Ilmu-ilmu keislaman pada waktu itu, termasuk di dalamnya Ilmu Ushul Fiqh mengalami proses pengkultusan dan pemandekan. Momentum puncak proses ini terjadi pada abad XIX, dimana sejak abad ini umat Islam banyak meninggalkan pemikiran Ushul Fiqh. Tidak seorangpun pemikir muslim yang mampu mengulangi langkah intelektual Al-Syafi'i. Hal ini disebabkan karena pengajaran Ushul

${ }^{8}$ Bandingkan dengan Wael B. Hallaq, A History of Islamic Legal Theories, Terj E. Kusnadiningrat,dan Abd. Haris bin wahid , "Sejarah Teori Hukum Islam”, (Jakarta: Rajawali Press, Cet II, 2001), h. 51

${ }^{9}$ Baca Hasan Hanafi, Dirasat Islamiyah, (Kairo :Maktabah Anglo Mishriyah,1987), h. 66-67

${ }^{10}$ M. Amin Abdullah, Paradigma..... Op.Cit, h. 117 
(Ushul Fiqh, Ushuluddin) hanya merupakan penumpukan dan pengulangan, tanpa pengembangan terhadap khazanah yang ada. ${ }^{11}$

Sehingga ilmu-ilmu keislaman termasuk Ushul Fiqh, sebagai arus utama ilmu-ilmu keislaman telah kehilangan progressitas dan elan vital. Dalam kondisi dan konteks inilah sangat penting dan urgen untuk membangun, merekontruksi dan meneguhkan kembali keberadaan Ilmu Ushul Figh yang pernah mengalami perkembangan yang luar biasa tersebut. ${ }^{12}$

Adalah Hasan Hanafi, seorang pemikir Mesir kontemporer yang mempunyai ide dan proyek besar dalam rangka pembangunan kembali ilmu-ilmu keislaman melalui usaha "revitalisasi khazanah klasik keislaman", ${ }^{13}$ termasuk diantaranya adalah khazanah Ilmu Ushul Figh. Proyek intelektual Hasan Hanafi ini termuat dalam karya ambisiusnya yang berjudul "Al Turas wa Al Tajdid" (Tradisi dan Modernisasi). Proyek revitalisasi khazanah klasik keislaman Hasan Hanafi didasarkan pada sebuah pemahaman bahwa pemikiran keislaman saat ini dan yang akan datang haruslah merupakan kelanjutan dan kontinuitas dari pemikiran Islam masa lalu (turas). Selain itu khazanah keislaman klasik sesungguhnya menyimpan kekayaan dan prestasi yang luar biasa yang harus dilestarikan dan lanjutkan. Oleh karena itu turas harus direvitalisasi, bukan hanya dipajang, dikutip dan disyarh. Turas hendaknya menjadi basis dan titik tolak bagi kekuatan revolusioner umat Islam. ${ }^{14}$

11 Muhamad Arkoun, Nalar Islam Dan Nalar Modern ; Berbagai Tantangan dan Jalan Baru, (Jakarta : INIS, 1994, Cet I), h. 52.

12 Tentang perdebatan perlu tidaknya pembaharuan Ilmu Ushul Fiqh dapat dibaca dalam Abdul Hamid Uways, al Figh al Islamy Bayna al Tathannur wa Al Tsabat,Terj A.Zarkasy Chumaidy, 'Fiqh Dinamis- Fiqh Statis”, (Bandung : Pustaka Hidayah 1998), h.150-170

${ }^{13}$ Menurut Hasan Hanafi, Khazanah klasik itu terdiri atas tiga macam ilmu pengetahuan, yaitu : Ilmu-ilmu normativ-rasional (al 'ulum an naqliyah al aqliyab) semisal Ilmu Ushuluddin, Ilmu Ushul Fiqh, Ilmu Hikmah dan Ilmu Tasawwuf. Ilmu-ilmu rasional semata (al aqliyah) semisal matematika, astronomi, fisika, kimia dll. Serta Ilmu Alqur'an, yaitu Ilmu Hadis, Sirah Nabi, Fiqih dan Tafsir. Selanjutnya baca dalam Kazuo Shimogaki, , Between Modernity and Postmodernity : TheIslamic Left and Dr. Hasan Hanafi's Thought, Terj M. Imam Aziz dan Jadul Maula ,"Kiri Islam : Antara Modernisme dan Postmodernisme; Telaah Kritis Pemikiran Hasan Hanafi”, (Yogyakarta: LKIS, Cet IV, 2000),h. 95-106.

${ }^{14}$ Lebih lanjut baca Islam Garda Depan : Mosaik Pemikiran Timur Tengah, M. Aunul Abied Syah (Ed), (Bandung : Mizan, 2001), h. 228 
Satu hal yang menarik tatkala penulis mengambil pemikiran Hasan Hanafi sebagai objek kajian Ushul Fiqh adalah latar belakang intelektual dan ketokohannya. Pada masa sekarang ini Hasan Hanafi barangkali menempati pemikir kelas pertama dalam level pemikir keislaman kontemporer yang tidak mungkin diragukan lagi dedikasi dan komitmen keislamannya. Ia dapat di sejajarkan dengan pemikir kontemporer seperti M. Arkoun, Fazlur Rahman, Nasr Abu Zayd maupun M. Abid Al-Jabiry. Namun satu hal yang menjadi nilai lebih dari Hasan Hanafi adalah bahwa tidak sebagaimana pemikir-pemikir yang telah disebutkan lalu yang bergulat pada pemahaman penggalan tertentu dari wacana keislaman, Hasan Hanafi adalah seorang filosof, ideolog dan pemikir kebudayaan yang menjadi bagian integral dan subjek dari perjuangan keislaman itu sendiri, bukan hanya pengamat ajaran Islam (Islamis). ${ }^{15}$

Selain itu Hasan Hanafi termasuk pemikir Islam yang jarang ditemui karena mempunyai disiplin ilmu yang beragam baik ilmu filsafat, politik, sosiologi, teologi dan fiqh. Keragaman disiplin ilmu itulah justru yang paling menarik ketika penulis mencoba menelaah pemikiran Ushul Fiqh Hasan Hanafi, karena disiplin hukum Islam tidak bisa dipisahkan begitu saja dari disiplin ilmu yang lain. Hukum Islam tentu saja secara implementasi dan operasional berkaitanb erat dengan ilmu sosiologi, sejarah dan bahkan politik. Disinilah terletak signifikansi dari pemikiran Ushul Fiqh Hasan Hanafi. Selain memang dia menyempatkan secara intensif untuk meneliti dan mengungkap tentang Ilmu Ushul Fiqh itu sendiri, sebagaimana dilakukan dalam tesisnya. ${ }^{16}$

\footnotetext{
${ }^{15}$ Selanjutnya baca M. Amin Abdullah dalam pengantar Ilham B, Saenong, Hermeneutika Pembebasan : Metodologi Tafsir Alqur'an Menurut Hasan Hanafi, (Bandung : Teraju, 2002), h. xvi.Dalam konteks ini Hasan Hanafi menandaskan kembali bahwa tugas seorang intelektual Islambukanlah hanya meneliti, menganalisa dan berkata seperti orang di luar Islam. Intelektual Islamadalah adalah orang dalam (abl al dar) yang merupakan bagian dari masalah umat Islam itu sendiri.Lebih dari itu intelektual muslim menurutnya, bukan hanya obyek, namun bertanggung jawab sepenuhnyaterhadap kondisi umat. Lihat dalam Hasan Hanafi, al Islam wa Tahadiyyat al Ashr, (JurnalJauhar, vol II, No. I, Juni, 2001), h. 178

${ }^{16}$ Tesisnya tersebut adalah Les Methodes d' Exegesse, Essai sur la Science des Fondaments des la Comprehension, Ilmu Ushul Fiqh, (Impremerie Nationale, le Caire, 1965)
} 
Secara geneaologis, penggunaan pendekatan kesejarahanan dalam studi Islam (baca: Ushul Figh) sudah dilakukan oleh para pemikir Islam terdahulu. Ibnu Rusyd adalah salah seorang pemikir Islam klasik yang sangat memahami pentingnya perkembangan zaman, sejarah dan perkembangan manusia dalam Ushul Fiqh. Dia mengatakan, sebagaimana dikutip oleh Hasan Hanafi: "Jika Ilmu Ushul Fiqh merupakan Ilmu pengambilan dalil maka Allah mewajibkan kepada manusia untuk mengamati dan beristidlal. Sedangkan manusia dikhususkan untuk membuat hujjah, dalil dan permisalan. Dan jika Islam merupakan risalah yang terakhir setelah terjadi perkembangan wahyu dan syariah, maka dengan demikian pengambilan hukum sudah seharusnya dibangun berlandaskan sejarah"17

Setelah itu diikuti Ibu Khaldun yang terkenal dengan teori 'ulumul umran dan thoba'I al umrannya. ${ }^{18}$ Dia menyatakan bahwa dalam kenyataannya sangat sedikit sekali persoalan kesyari'ahan itu bertentangan dengan realitas empiris. ${ }^{19}$ Imam al- Syatibi yang terkenal dengan kitab al-Muwafaqatnya adalah generasi pemikir Islam yang melanjutkan tradisi berfikir historis ini. Teorinya tentang al-kulliyah alsyar'iyyah, maqashid al-syariah dan al-kulliyah al-Imiyah adalah bukti empiris dari pemikiran As-Syathibi tentang hal ini ${ }^{20}$ Metodologi pemikiran keislaman secara historis ini kemudian dilanjutkan oleh para pemikir muslim kontemporer seperti M. Arkoun, ${ }^{21}$ Fazlur Rahman $^{22}$ dan Hasan Hanafi. ${ }^{23}$

${ }^{17}$ Baca Hasan Hanafi, Min al Naql ila al ibda', (Dar Quba' wa Nasyr wa al Yauzi', 1990, Jilid I), h. 327.

18 Selanjutnya baca Ibnu Khaldun, Tarikh Ibnu Khaldun, (Beirut: Dar al Kutub al 'Ilmiyah,1998, Jilid I, Cet I), h. 36-43

${ }^{19}$ Baca dalam M.Abid Al Jabiry, Post Tradisionalisme Islam, terj Ahmad Baso, (Yogyakarta : LKIS, 2001), h. 178

${ }^{20}$ M. Abid al Jabiry, Op.Cit, h. 167

${ }^{21}$ Pemikiran Historisnya dapat kita baca dalam karyanya Tarikhiyyah al Fiker al Araby al Islamy, (Lebanon, Mansyarat Markaz al Inma' al Qaumy, Cet I, 1896)

${ }^{22}$ Tentang pemikiran historisnya terurai dalam bukunya Islamic Methodology in History, (Karachi :Central Institue of Islamic Research, 1965)

${ }^{23}$ Diantara buku yang yang secara detail membahas persoalan ini adalah Dirasat Islamiyah, (Kairo :Maktabah Anglo Mishriyah,1987) 
Substansi pemikiran dan pendekatan yang digunakan oleh Hasan Hanafi dalam melakukan revitalisasi ${ }^{24}$ terhadap Ilmu Ushul Fiqh adalah apa yang dia sebut sebagai pendekatan historis (alwa'yu al tarikby), ${ }^{25}$ yaitu sebuah pendekatan yang digunakan untuk memahami, mengungkap dan merepresentasikan konsepsi-konsepsi Ushul Fiqh berdasar pada kondisi ruang sejarah dan kemanusiaan. Menurutnya Ushul Fiqh harus ada di dalamnya gerakan sejarah (harakah al-tarikh) dan dimensi ilmu kemanusiaan ('ulumul insan). Hanya dengan pendekatan dan pengintegrasian entitasentitas tersebut Ilmu Ushul Fiqh dapat memproduksi hukum Islam yang dapat berdialektika dengan zaman serta sesuai dengan kebutuhan kemanusiaan. ${ }^{26}$

Sesungguhnya dimensi manusia dan sejarah sangat kuat dalam ilmu-ilmu keislaman klasik, namun seringkali tersembunyi atau sengaja disembunyikan di balik kuatnya pencitraan tentang Tuhan. ${ }^{27}$ Dalam hal inilah usaha revitalisasi terhadap Ilmu Ushul Fiqh menjadi sebuah keniscayaan, karena kebutuhan untuk menghadirkan kembali ruh dan élan vital Ilmu Ushul Fiqh yang telah "terkubur" lama bersamaan dengan hilangnya dimensi kemanusiaan dan sejarah dalam proses pembentukan dan perkembangnya.

Persoalan dan sesuatu yang ingin diungkap, diketahui dan dirumuskan dalam penelitian ini adalah : 1). Bagaimana konstruksi

${ }^{24}$ Revitalisasi secara bahasa berasal dari bahasa Inggris "vitalize” yang berarti menghidupkan kembali atau menyajikan dalam keadaan hidup, baca Peter L. Salim, The Contemporary English-Indonesian Dictionary,, (Jakarta: Media English Press, ed 6, 1991), h. 2240. Istilah ini biasanya digunakan dalam konteks "pembaharuan atau memperbaharuai". Azumardi Azra menggunakan istilah ini dalam memaknai proses pembaharuan agama Islam yang terjadi di Kalimantan Selatan dalam kasus Jihad Pangeran Hidayatullah . Lihat Azumardi Azra, Islam Reformis: Dinamika Intelektual danGerakan, (Jakarta, Rajawali Press, 1999), h. 253-266. Sedangkan dalam konteks pemikiran Hasan Hanafi, Istilah ini digunakan oleh Kazuo Shimogaki tatkala menganalisis posisi pemikiran Hasan Hanafi terhadap khazanah dan tradisi klasik Islam, Lihat Kazou Shimogaki, Op.Cit. h. 92. Istilah ini juga digunakan oleh M. Amin Abdullah dalam memaknai apa yang telah dilakukan oleh para ulama Ushul Fiqh kontemporer terhadap pemikiran Ushul Fiqh para Ushuliyyun pada zaman sebelumnya. Selanjutnya baca M. Amin Abdullah, Paradigma Alternatfi....., op.cit,h. 118

${ }^{25}$ Selanjutnya baca Hasan Hanafi, al Din wa al Tsaqafah wa al Siyasah fi al Wathan al'Araby, (Kairo: Dar Quba' li al Thiba'ah wa al Nasyr, 1997), h. 32

${ }^{26}$ Selanjutnya baca Hasan Hanafi, Dirasat Islamiyah, op.cit, h. 436 dan 407

${ }^{27}$ Bandingkan dengan M. Amin Abdullah dalam Pengantar Ilham B. Saenong, Hermeneutika pembebasan..., op. cit, h. xvii. 
pemikiran Ushul Fiqh Hasan Hanafi?; 2). Bagaimana Penerapan pendekatan historis Hasan Hanafi dalam rangka rekonstruksi Ilmu Ushul Fiqh?; 3). Bagaimana relevansi pemikiran Ushul Fiqh Hasan Hanafi terhadap upaya reaktualisasi hukum Islam?

\section{B. Kerangka Teori}

Penelitian yang akan dilakukan kali ini sesungguhnya berdasarkan pada sebuah hipotesis bahwa reaktualisasi hukum Islam adalah kebutuhan yang mendasar bagi umat Islam menghadapi problematika kemasyarakatan yang semakin kopleks. Reaktualisasi hukum Islam ini haruslah berpijak pada teori (epistemologi) Hukum Islam itu sendiri, karena tanpa itu pembaharuan hukum Islam tidak akan mempunyai kerangka teoritik (theortycal frame) yang kuat. ${ }^{28}$

Ushul Fiqh sebagai teori dan epistemologi hukum Islam dengan demikian sangat mendesak untuk dilakukan proses ini, karena sejarah telah membuktikan bahwa Ushul Figh walaupun pada awalnya merupakan karya yang luar biasa yang diciptakan oleh para ushuliyyun, akan tetapi pada proses selanjutnya mengalami sakralisasi dan pembakuan ${ }^{29}$ sehingga kehilangan ruh dan élan vital. Hal ini disebabkan karena Ilmu Ushul Fiqh telah kehilangan dimensi sejarah dan kemanusiaan, ${ }^{30}$ padahal pada awal mulanya metodologi Islam seperti al Qur'an, Sunah, Ijma' dan Qiyas mengalami sebuah proses evolusi sejarah. ${ }^{31}$ Dalam konteks ini maka usaha revitalisasi Ushul Fiqh adalah sangat signifikan untuk dilakukan. Hasan Hanafi adalah seorang tokoh dan pemikir kontemporer yang peduli dan concern terhadap persoalaan ini, yaitu usaha revitalisasi Ilmu Ushul Fiqh. Dengan menggunakan pendekatan historis, yaitu memaknai dengan melibatkan dimensi kemanusiaan dan sejarah, Hasan Hanafi mencoba menginterpretasikan ulang konsepkonsep Ilmu Ushul Fiqh yang diproduksi oleh para Ushuliyyun.

\footnotetext{
${ }^{28}$ M. Amin Abdullah, Paradigma Alternatif...., op.cit, h. 121

${ }^{29}$ Baca M. Arkoun, Nalar Modern ........., op.cit, h. 52

${ }^{30}$ Baca Hasan Hanafi, Dirasat......, op..cit, h. 436 dan 407

${ }^{31}$ Baca Fazlur Rahman, Islamic Methodology........., op.cit, h. vii
} 


\section{Riwayat Hidup Hasan Hanafi}

Dalam kondisi transformasi sosial dan politik bangsa Mesir yang sangat fundamental seperti itu, seorang pemikir Mesir kontemporer bernama Hasan Hanafi lahir, berkembang dan mengartikulasikan pemikiran serta aktifismenya. Hasan Hanafi lahir pada tanggal 13 Pebruari 1935 di Kota kairo. Ia lahir dari keluarga musisi sehingga mengalir dalam jiwanya darah seni dan estetika. Pada tahun 1948 ia menyelesaikan pendidikan dasarnya. Kemudian ia melanjutkan ke Madrasah Tsanawiyah Khalil Agha. Pada masa Hasan Hanafi menginjak usia remaja bangsa Mesir masih berada di bawah penjajahan Inggris, pada masa inilah muncul sebuah "kesadaran nasionalisme" dalam diri Hasan hanafi. Sejak sekolah ia mulai akrab dengan pemikiran dan gerakan Ikhwanul Muslimin. Setelah melanjutkan kuliah pada Universitas Kairo, jurusan Filsafat ia mulai total dan terjun secara langsung dalam dunia aktivisme Mahasiswa.Ia menjadi tokoh penting dalam gerakan mahasiswa Ikhwanul Muslimin di Perguruan tingginya. Dalam dunia Mahasiswa inilah mulai terbentuk mentalitas dan karakternya sebagai seorang aktivis muslim. Dengan demikian ia adalah tokoh yang benar-benar berangkat dari dunia aktivis. Hasan Hanafi sangat mengagumi pemikiran tokoh Ikhwan waktu itu. Nama-nama seperti Hasan al Banna, Sayyid Qutb dan Muhammad al Ghazali sangat berpengaruh dalam membentuk cetak biru pemikiran dan kesadaran keislaman Hasan hanafi, bersamaan dengan itulah "kesadaran keagamaan" Hasan hanafi mulai mewujud dalam Benaknya. ${ }^{32}$

Setelah terjadi penekanan dan pencekalan terhadap beberapa tokoh Ikhwan pada masa pemerintahan Gamel Abdul Naseer, pada waktu yang bersamaan, namun pada konteks yang lain terjadi "evolusi pemikiran" pada diri Hasan Hanafi. Hasan Hanafi merasa bahwa apa yang selama ini difahami dan digelutinya dalam naungan Ikhwanul Muslimin tidak menyentuh dan memberi solusi terhadap persoalan keislaman yang ada saat ini. Apa yang diajarkan oleh para pengajar di dalam ruangan menurutnya tidaklah sama seperti apa

32 Selanjutnya baca Hasan Hanafi, al Ushulyyah al Islamiyah dalam al Din wa al Tasaurah, fi Mishr, Terj Kamran As'ad, “Aku Bagian dari Fundamentalisme islam”, (Yogyakarta, Studi Islamika, 2003),h. 32 
yang berada dalam masyarakat secara empiris. ${ }^{33}$ Dalam kondisi kegundahan dan pergeseran paradigma pemahamaan keagamaan seperti ini Hasan Hanafi memutuskan untuk terus bergelut dalam dunia intelektualisme dengan melanjutkan studinya di Universitas Sorbone, Perancis setelah kelulusannya dari Universitas Kairo pada tahun 1956.

Ketika di Perancis Hasan Hanafi mulai bergelut dengan dunia Filsafat Barat. Pemikiran Aristotetels, Plato, Fitche dan Husserl sangat mempengaruhi pandangan dan pemikiran keagamaan Hasan Hanafi. Pada saat inilah ia mendifinisikan dirinya bahwa ia sampai kepada kesadaraan baru yang ia sebut sebagai"kesadaran filosofis" yaitu pada akhir tahun 1950-an. Walaupun demikian Hasan Hanafi sesungguhnya sudah akrab dengan pemikiran para filosof Islam seperti Muhammad Iqbal dan Jamaluddin al Afghani selama ia duduk di Universitas al Azhar. Ia kemudian mendapat gelar doctor setelah menyelesaikan Disertasi dan tesisnya yang berjudul "Les Methodes d'exegese : Essai sur La scienc des fondaments de la comprehension,Ilm Ushul Fiqh". dan "L'exegese de la phenomenologie. L'Etat actuel de lamethode phenomenologique et son application au phenomene religieux". Yaitu karya yang membahas Ilmu Ushul Fiqh dengan menghadapkan ilmu ini pada filsafat fenomenologi. ${ }^{34}$

Pada tahun 1966 Ia pulang dari Perancis. Setelah itu ia diangkat menjadi Lektor di Universitas Kairo. Tahun 1973 ia menjadi Lektor kepala dan tahun 1980 ia mendapat gelar professor di bidang filsafat. Tahun 1988 ia diangkat menjadi ketua jurusan filsafat di Universitas Kairo. Selain menjadi pengajar tetap di almamaternya, Hasan Hanafi juga memberi kuliah di beberapa Universitas luar negeri. Seperti di Perancis (1969), Temple University Philadelphia (1971-1975). Universitas Kuwait (1979), Universitas Ves Maroko

${ }^{33}$ Walaupun begitu secara "ruh perjuangan" Hasan Hanafi masih menganggap Sayyid Qutb sebagai seorang yang memberi inspirasi terhadap kehidupan keberislamnnya. Bahkan sampai ia kembali lagi dari Perancis ia mengatakan bahwa Sayyid Qutb adalah orang yang paling berpengaruh dalam kehidupannya, lebih lanjut baca Hasan Hanafi, Ibid, h. 52

34 Abdurrahman Wahid dalam pengantar Kazuo Shimogaki, Between Modernity and Postmodernity : The Islamic Left and Dr. Hasan Hanafi's Thought, Terj M. Imam Aziz dan JadulMaula ,"Kiri Islam : Antara modernisme dan Postmodernisme ; Telaah Kritis pemikiran HasanHanafi”, (Yogyakarta: LKIS, Cet IV, 2000), h. xi. 
(1982-1984) dan menjadi guru besar tamu di Universitas Tokyo (1984-1985), Persatuan Emirat arab (1985) dan Penasehat

Program pada Universitas PBB di Jepang (1985-1987). ${ }^{35}$ Selain mengajar, Hasan Hanafi melaksanakan perannya untuk melaksanakan pengabdian terhadap masyarakat. Ia tercatat aktif di beberapa organisasi, antara lain: ia menjadi Sekretaris Umum Persatuan Masayarakat Filsafat Mesir, Anggota Ikatan Penulis AsiaAfrika, Anggota pada Gerakan Solidaritas Asia-Afrika dan Wakil Persaudaraan Masyarakat Filsafat Arab. ${ }^{36}$

Pada tahunn 1967 setelah kepulangannya dari Perancis ia mulai mengerjakan proyek intelektualnya yang ia berinama "al Turas wa al Tajdid", pada waktu ia mulai mengerjakan proyeknya tersebut, meletuslah perang Arab yang berakhir dengan kemenangan Israel. Melihat kondisi demikian ia menghentikan sejenak penulisan karya tersebut untuk melakukan refleksi terhadap apa yang terjadi terhadap umat islam. Pada masa-masa inilah ia kemudian mendefinisikan dirinya sampai kepada kesadaran baru yang ia sebut sebagi "kedaran politik", yaitu sebuah kesadaran filosofis akan kondisi politik umat Islam di tengah percaturan bangsa barat,walaupun memang ia tidak pernah bergelut dalam dunia politik praktis.

Pada tahun 1981 Hasan Hanafi memprakarsai terbitnya jurnal ilmiyah yang bernama "al Yasar al Islamy". Jurnal yang merepresentasikan otentitas pemikirannya yang revolusioner dan berfihak kepada kaum tertindas. "Kiri Islam” sebagai icon pemikiran Hasan Hanafi pada waktu itu mampu menggugah dan menampilkan alternatif pemikiran Islam di kawasan Arab, terutama di Mesir.

\section{Pemikiran Hasan Hanafi tentang Revitalisasi Metodologi}

\section{Ushul Fiqh.}

Sebelum membahas tentang revitalisasi metodologi Ushul Fiqh yang dilakukan oleh Hasan Hanafi, terlebih dahulu harus memahami dan menafsirkan apa sesungguhnya makna dan istilah dari

${ }^{35}$ A.H. Ridwan, Reformasi Intelektual Islam : Pemikiran Hasan Hanafi tentang Reaktualisasi Tradisi Keislaman, (Jakarta Ittiqa Press), h. 16

${ }^{36}$ Ibid, 
"revitalisasi". Secara bahasa, istilah ini berasal dari kata "vitalize" yang berarti menghidupkan kembali atau menyajikan dalam keadaan hidup. ${ }^{37}$

Dalam konteks Ushul Figh usaha revitalisasi telah menjadi bagian yang dilakukan oleh para pakar Ilmu Ushul Fiqh. Dalam artian bahwa para ulama Ushul Fiqh pada waktu dan zaman tertentu dalam rangka membangun metodologi Ushul Fiqh untuk merespon dan memberi solusi terhadap persoalan hukum waktu itu mendasarkan pada konsep-konsep yang telah ada yang dibangun oleh para ulama Ushul Fiqh terdahulu, namun pada waktu yang sama mereka melakukan penyesuaian dan penafsiran metodologi yang dibangun oleh ulama Ushul Figh terdahulu tersebut dengan kondisi dan konteks historis pada zamannya. Hal ini sesuai dengan apa yang diungkapkan oleh M. Amin Abdullah : Enam abad kemudian, sumbangan as Syatibi pada abad ke-8 H/14 M itu, direvitalisasi oleh para pembaharu Ushul Fiqh di dunia modern, seperti Muhammad abduh (w.1966), Rasyid Ridla (w.1935), Abdul wahab Khallaf (w. 1956), Allal al fasi (w. 1973) dan Hasan Turabi. ${ }^{38}$

Hal ini mengindikasikan bahwa usaha revitalisasi Ushul Figh telah menjadi bagian yang tidak bisa dipisahkan dari keberadaan Ilmu ini dan menjadi proses yang terjadi secara terus menerus dan berulang-ulang oleh para ulama Ushul Fiqh sepanjang sejarah.

Jika kita asumsikan bahwa Ilmu Ushul Figh muncul dan berdiri di tangan Imam Syafi'I dengan ar-Risalahnya, maka proses revitalisasi Ushul Fiqh juga terjadi pada waktu itu juga. As-Syafi'I membangun fondasi metodologi Ushul Fiqh waktu itu berdasar pada sebuah refleksi terhadap khazanah metodologi yang ada pada ulama sebelumnya yang mensintesakan antara dua kecenderuingan metodologi yang saling bertolak belakang pada waktu itu, yaitu abl al hadis dan abl ra'yi. Corak pemikiran Ushul Fiqh ini kemudian diikuti oleh para ahli Ushul mazhab mutakallimun. Walaupun masih dalam satu paradigma, yaitu paradigma literalisme, namun sesungguhnya proses revitalisasi juga terjadi pada waktu itu. Hal ini dapat kita

37 Peter L. Salim, The Contemporary English-Indonesian Dictionary,, Jakarta: Media English Press, ed 6, 1991), h. 2240.

${ }^{38}$ M. Amin abdullah, Paradigma Alternatif Pengembangan Ushul Figh dan Dampaknya pada Fiqh Kontemporer dalam "Mazhab Jogja: Membangun Paradigma Ushul Fiqh Kontemporer”,Ainurrofiq(Ed), (Yogyakarta: Arruz, 2004), h. 118 
ketahui tepatnya pada ke-5/11, ketika para ulama Ushul berhasil membangun sebuah konstruksi Ilmu Ushul Fiqh secara lebih sistematis dan ilmiah. Berbeda dengan masa-masa sebelumnya para ulama Ushul fiqh pada masa ini telah memfokuskan pada kesadaran yang tajam terhadap struktur, tentang tekstualitas hukum serta membangun metodologi berdasarkan pertimbangan epistemologis sebuah teks serta implikasi linguistiknya. Selain itu mereka juga membangun prinsip-prinsip otentitas sebuah dalil syara'. ${ }^{39}$

Pada Abad ke-8 muncul as-Syatibi yang berhasil merevitalisasi Ilmu Ushul Fiqh dengan menambah sebuah teori yang terkenal yaitu teori maqashid al syariah. Dengan munculnya teori ini, Ilmu Ushul Fiqh telah mengalami dinamika dan pergeseran paradigma yang sangat fundamental, yaitu dari paradigma literal menuju paradigm kontekstual-positisvitik, ${ }^{40}$ dari nash menuju realitas. Pemikiran Ushul Fiqh as Syatibi inilah yang kemudian diikuti dan direvitalisasi juga oleh para ulama Ushul modern.

Salah seorang pemikir modern yang mencoba melakukan revitalisasi terhadap Ilmu Ushul Fiqh adalah Hasan Hanafi. Pemikiran revitalisasi Ilmu Ushul Figh ini dibahas secara intens dalam tesisnya yang berjudul Les Methodes d' Exegesse, Essai surla Science des Fondaments de la Comprehension, Ilmu Ushul Figh. Main stream pemikirannya tersebut tersebar di beberapa karyanya yang lain seperti dalam DirasatIslamiyah. Dalam buku yang terakhir ini Hasan Hanafi memaparkan secara komprehensip beberapa ide dan kosepnya tentang upaya pembaharuan dan pengembangan Ushul Fiqh yang berdasar pada konsep yang dibangun oleh para ulama terdahulu. "al ashalah" dan "al mua'asharah" itulah barang kali slogan yang dipakai oleh Hasan Hanafi dalam membangun Ilmu Ushul Fiqh. Dalam konteks inilah komentar dia tentang perkembangan Ushul Fiqh dapat kita maknai, demikian komentarnya : Dan bangunan Ilmu Ushul Fiqh telah mengalami perkembangan sejak munculnya kitab ar Risalah karya as Syafi'I sehingga Ilmu ini mengalami pembakuan ke dalam

${ }^{39}$ Selanjutnya baca Wael B. Hallaq, A History of Islamic Legal Theories, Terj, E. Kusnadiningrat,dan Abd. Haris bin wahid, "Sejarah Teori Hukum Islam ",(Jakarta: Rajawali Press, Cet II, 2001), h. 53-55

${ }^{40}$ Tentang nuansa postivisme dalam pemikiran Ushul Fiqh as Syatibi dapat diketahui dalam M.K. Mas'ud, Syathibi's Philosophy of Islamic Law, (Delhi:Adam Publishers and Distributors, 1997), h. 20-21 
empat entitas (al taqsim al ruba'iy), Adapun mayoritas Ushuliyun banyak yang hanya menampilkan metodologi para pendahulu mereka sebagaimana yang terjadi dalam kitab al lumu' karya al Syairazy ( 486 H). Kemudian materi Ushul ini berubah menjadi beberapa bab, tema dan buku. As Syaukani dalam Irsyad al fubulnya menulis tujuh bab, al Ghazali dalam al mankhul menulis 14 bab. Al Qarafy menulis 20 bab dan Ibnu Hazm menulis 40 bab. Adapun al Amidi dan as Syatibi menempatkan empat entitas ini sebagai bagian yang tidak boleh terpisahkan dari Ilmu Ushul Fiqh. (yaitu abkam syar'iyah, adillah syar'iyah, thuruq al istidlal dan abkam al ijtihadtaqlid) dan jika ilmu Ushul Fiqh adalah metodologi yang berorientasi kepada mukallaf sebagaimana maksud dari wahyu itu sendiri, maka harus ada tiga kesadaran disana; yaitu kesadaran historis, kesadaran reflektif dan kesadaran praxis. ${ }^{41}$

Komentar Hasan Hanafi diatas mengindikasikan akan posisinya dalam konteks revitalisasi Ushul Fiqh. Ia secara implisit mengatakan bahwa metodologi Ushul Fiqh yang dibangunnya merupakan kontinyuitas dari metodologi yang dibangun oleh para ulama Ushul terdahulu, bahkan sampai Imam Syafi'i.

Dalam rangka membangun metodologi Ushul Fiqh yang kuat secara telogis dan praxis, Hasan Hanafi mensyaratkan akan pentingnya pengintegrasian ilmu ini dengan Ilmu Kalam, Ilmu Bahasa dan Ilmu hukum syara' (Fiqh). Pertama, Ilmu Kalam, fungsinya adalah dalam rangka mendialogkan dalil-dalil syar'iyyah dengan persoalanpersoalan kalam seperti perbuatan, kebaikan dan keburukan. Yang Kedua adalah Ilmu Bahasa Arab. Karena yang dibahas adalah lafaz-lafaz, yang dengannya akan sempurna pemahaman tentang ushul-ushul yang termaktub yang berkaitan pula dengan kaidah-kaidah bahasa arab. Yang Ketiga Ilmu tentang Hukum Syara'. Karena tujuannya adalah untuk menetapkan atau menafikan sebuah hukum, ${ }^{42}$ serta melaksanakan hasil metodologi istimbat tersebut.

Pemaparan Hasan Hanafi diatas mengisyaratkan bahwa Ilmu Ushul Fiqh haruslah selaras dengan ilmu-ilmu lain sehingga ia

${ }^{41}$ Baca Hasan Hanafi, Dirasat Islamiyah, (Kairo :Maktabah Anglo Mishriyah,1987), h. 60

${ }^{42}$ Ibid, h. 55-56 
tidaklah tercerabut dari fundamen ilmu-ilmu keislaman yang ada. Jika Ilmu Ushulluddin membahas pokok-pokok agama yang bersifat idealistik-spiritual murni, maka Ilmu Ushul Figh menjadi dasar hukum-hukum yang mempunyai dimensi sosial, historis,kultural, ideologis bahkan etnografis. ${ }^{43}$

Maka dengan demikian Ilmu Ushul Fiqh adalah operasionalisasi dari Ilmu Ushuluddin. Sedangkan dalam kaitan dengan Ilmu Fiqh dapat dikatakan bahwa Ilmu Ushul Fiqh merupakan epistemologi bagi Fiqh. Dalam konteks ini maka Ilmu Ushul Fiqh lebih bersifat elastis, terbuka dan fleksibel. Jika Fiqh mendasarkan dirinya pada dalil-dalil tafsily dan tekstual (naqly) semata, ${ }^{44}$ maka Ilmu Ushul Fiqh mendasarkan dirinya pada dalil-dalil yang bersifat kully dan berkonsentrasi pada pembangunan metodologi istinbat.

Sedangkan hubungan antara Ilmu Ushul Fiqh dan Ilmu Bahasa adalah bahwa Ilmu Bahasa (Arab) digunakan untuk kepentingan pembangunan metodologi Ushul Fiqh dan menjadi bagian yang include dan integral dari ilmu ini.

Dalam konteks revitalisasi terhadap Ilmu Ushul Fiqh Hasan Hanafi menawarkan pembaharuan metodologis dalam upaya istinbat hukum syara' yang berakar pada teorinya tentang "kesadaran". Yaitu Pertama, al Syu'ur al Tarikby adalah kesadaran bagi seorang perawi yang fungsinya menjamin kesahihan dan otentitas nash-nash wahyu dalam sejarah. ${ }^{45} \mathrm{Kedua}$, al syu'ur al ta'ammuly, berfungsi memahami nash-nash dan menafsirkannya setelah ada keyakinan dan kepastian terhadap kesadaran kesejarahan dalam hal otentitas dan pentasyr'iannya. Bagian ini merupakan yang terpenting dalam Ilmu Ushul fiqh, karena ini merupakan bagian metodologis yang dengannya akan sempurna sebuah proses istinbat. Karena disinilah terrealisir sebuah usaha manusia untuk memahami dan menakwilkan. ${ }^{46}$ Yang ketiga adalah al syu'ur al 'amaly, Yaitu sebuah kesadaran melaksanakan hukum-hukum serta mengimplementasikan

${ }^{43}$ Ainurrofiq, Menawarkan Epistemologi Jama'I Sebagai Epistemologi Ushul Fiqh: Sebuah: Tinjauan Filosofis dalam "Mazhab Jogja: Membangun Paradigma Ushul Figh Kontemporer”,(Yogyakarta: Arruz, 2004), h. 46

${ }^{44} \mathrm{Ibid}$, h. 47

${ }^{45}$ Hasan Hanafi, Op.Cit,h. 69

${ }^{46}$ Hasan hanafi, Dirasat..., Op. cit, h. 78. 
perintahperintah dan larangan untuk mengubah wahyu menjadi perbuatan ke dalam dunia nyata dan di dalam gerakan sejarah. Para ushuliyyun menganggap ini sebagai hasil dari istimbath (tsamrah). ${ }^{47}$

Ketiga kesadaran ini merupakan entitas yang sangat mendasar yang menjadi frame dasar bagi pemikiran Ushul Figh Hasan Hanafi. Dengan berpangkal pada ketiga kesadaran ini, Hasan Hanafi mencoba mengelaborasi metodologi Ushul Fiqh secara lebih mendetail dan terperinci. Sistematisasi yang dilakukan Hasan Hanafi terhadap metodologi Ushul Fiqh menjadi ketiga kesadaran tersebut merupakan sebuah langkah yang otentik dan memberi kontribusi yang berarti bagi khazanah pemikiran Ushul Fiqh kontemporer.

Dalam hal adillah syar'iyah, revitalisasi yang dilakukan oleh Hasan Hanafi adalah penegasannya kembali akan sebuah visi dan kesadaran dalam adillab syar'iyah yang berarti bahwa sumber-sumber syari'ah harus difahami dan diuji terlebih dahulu keotentikan dan kesejarahannya, terutama al Qur'an dan Sunah.

Al Qur'an, menurut Hasan Hanafi sudah tidak diragukan lagi keotentikannya, kecuali dalam persoalan bahasa dan beberapa persoalan yang berujung pada masa tadwin. Sesuatu yang perlu untuk dipersoalkan dalam pembahasan tentang al Qur'an adalah persoalan nasikh-mansukh. Hasan Hanafi kemudian mengambil kesimpulan bahwa hakekat adanya naskh dalam al Qur'an adalah menunjukkan keberadaan wahyu dalam zaman. Wahyu ini kemudian berubah sesuai kapasitas dan dinamika individu dan masyarakat dalam sejarah. ${ }^{48}$

Dalam Sunah, periwayatannnya sangat berbeda dengan al Qur'an . Jika al Qur'an menggunakan periwayatan secara tertulis, maka Sunnah menggunakan metode periwayatan secara lisan yang membutuhkan sebuah metode yang sistematis, dan dapat dipertanggung jawabkan.Dalam konteks ini, menurut Hasan Hanafi ulama telah menyusun sebuah ilmu periwayatan (Ilmu Hadis) yang sangat luar biasa dalam sejarah muslim. Metode periwayatan historis ini sesungguhnya sudah lama ada sebelum munculnya ilmu kritik

\footnotetext{
${ }^{47}$ Ibid

${ }^{48}$ Hasan Hanafi, Dirasat...., Op.Cit, h. 81
} 
historis terhadap kitab suci yang populer di Barat dan diintrodusir oleh para orientalis. ${ }^{49}$

Revitalisasi dalam Ijma' dilakukan oleh Hasan Hanafi tatkala mendefinisikan ijma' dengan kesepakatan umat Islam atas persoalan keagamaan. ${ }^{50}$ Definisi ini sangat jauh berbeda jika kita bandingkan dengan definisi yang diberikan oleh para ulama Ushul terdahulu yang mendefinisikan ijma' sebagai konsensus para mujtahid dari kalangan umat Muhammad setelah beliau wafat, pada suatu masa, atas suatu hukum syara. ${ }^{51}$

Definisi ini sangatlah berimplikasi terhadap kehujjahan ijma'. Dengan definisi ini beberapa ulama Ushul terdahulu seperti Imam Syafi'I dan Imam Hambali misalnya menafikan adanya ijma' ${ }^{52}$ kecuali pada masa sahabat. Maka dalam hal ijma', revitalisasi Hasan Hanafi terdapat pada usahanya yang mencoba mengembalikan dan merasionalisasi makna ijma' sebagai kesepakatan umat yang bersifat lokal dan temporal berdasar kemaslahatan dan konsensus umat. ${ }^{53}$ Ijma' yang terdahulu, bagi Hasan Hanafi tidak harus dikuti oleh sesudahnya,namun setiap masa mempunyai Ijma'nya sendiri. ${ }^{54}$

Sedangkan dalam Qiyas, menurut Hasan Hanafi secara substansi identik dengan beberapa terminologi seperti istislah, istishab dan ijtihad. Setelah menelaah definisi yang diungkapkan oleh para ulama Ushul terdahulu, akhirnya ia berkesimpulan bahwa qiyas menunjukkan kepada pembahasan tentang lafal, sesuatu yang diambil dari yang lain, mengeluarkan sebuah hukum atas yang lain serta membawa sesuatu kepada yang lain dari segi lafal dalam hal mafhum dan makna. ${ }^{55}$ Qiyas, menurutnya adalah sebuah pekerjaan akal dalam

${ }^{49}$ Ibid

${ }^{50}$ Ibid, h. 83

51 Definisi ini diberikan oleh oleh beberapa ulama Ushul, misalnya Ibn Amir al Haj, al Syaukani, Wahbah Zuhaily dan Abd. Wahab Khalaf. Selanjutnya baca Nasrudin Ruli, Konsep Ijtihad as Syaukani :Relevansinya Bagi Pemabaharuan Hukum Islam di Indonesia, (Jakarta : Logos Wacana Ilmu, 1999), h. 29

5216 'Tentang tidak menganggapnya Imam Syafi'I kehujjahan Ijma' kecuali pada masa Nabi dapat dilihat dalam ArRrisalah, Terj: Ahmadie Thoha, (Jakarta, Cet IV, 1996), h. 223-224. Selanjutnya baca Ibid, h. 30

${ }^{53} \mathrm{Ibid}$, h. 85

${ }^{54}$ Hasan Hanafi, Huwar al Ajyal, (Kairo; Dar Quba' Li al Thiba'ah wa al tauzi',1980), h. 458

${ }^{55}$ Hasan Hanafi, Dirasat ...... Op cit,, h. 86 
rangka melakukan proses mediasi (al tawassuth) antara nash dan realitas, yang merupakan entitas ketiga dari wahyu, ${ }^{56}$ bukan sebaliknya usaha untuk menyempitkan peran akal. Hasan Hanafi membagi realisasi metodologi ini dalam dua relisasi. Realisasi pertama adalah istinbat, yang bertitik tolak dari nash dan hal yang bersifat terdahulu (muqaddimat). Sedangkan realisasi yang kedua adalah istigra' yang mana obyeknya adalah realitas alam di luar teks. ${ }^{57}$ Maka dengan demikian Qiyas bagi Hasan Hanafi, mempunyai dua paradigma, yaitu paradigma deduktif dan induktif. Dalil ini, yang kemudian menurut Hasan Hanafi dijadikan oleh M. Iqbal sebagai sumber gerak sejarah dan solusi terhadap tertutupnya pintu ijtihad di kalangan umat Islam.

Sedangkan dalam thuruq al istinbat revitalisasi Hasan Hanafi berlangsung tatkala ia mengembalikan visi dan orientasi entitas ini pada sebuah kesadaran untuk melakukan sebuah refleksi terhadap dalil-dalil syara' dan bahwa thuruq al istinbath (pembahasan tentang lafal, ism dan illah) merupakan sebuah fase metodologis (al juz'u al manhajy) yang dengannya proses istinbat akan terjadi. ${ }^{58}$

Adapun dalam abkam syariyah revitalisasi Hasan Hanafi terletak tatkala dia menginterpretasikan al abkam syariyah sebagai sebuah kesadaran praxis. Artinya abkamsyar'iyah merupakan hasil sekaligus pelaksanaan dari hukum syara'. ${ }^{59}$

Dalam pembahasan tentang abkam syariyah, para ulama Ushul membagi menjadi empat entitas. Pertama adalah al hakim, yaitu al syari'. Kedua mabkum 'alaih, yaitu mukallaf. Ketiga mabkum fib, yaitu perbuatan manusia dan keempat, al bukm, yaitu al amr dan al naby. Hasan Hanafi kemudian mengemukakan analisanya bahwa pembagian ah kam syar'iyah tersebut berubah ketika al Syatibi memisahkan sebuah kesadaran praxis menjadi tema tersendiri dan memberinya prioritas yang lebih dari teori (ilmu). ${ }^{60}$

${ }^{56}$ Yang dimaksud dengan wahyu ketiga adalah bahwa teks (nash) adalah realisasi wahyu yang pertama, realitas adalah realisasi wahyu yang kedua dan akal adalah realisasi wahyu yang ketiga.

${ }^{57}$ Hasan Hanafi, Huwar...... Op cit, h. 458

${ }^{58}$ Ibid, h. 78.

${ }^{59}$ Ibid, h. 94

${ }^{60}$ Ibid, h. $94-95$ 
As Syatibi, menurut Hasan Hanafi, mengubah pembagian yang empat dalam abkam al syari'ah ${ }^{61}$ menjadi dua, yaitu al abkam dan al maqashid. Abkam dibagi menjadi abkam taklify yang berarti perbuatan manusia di dunia sesuai tingkat perbuatan dan kemampuan manusia untuk melaksanakannya dan abkam wadl'iy yang bermakna hukum yang diletakkan di dunia sebelum manusia melaksanakannya yang berdasarkan pada prinsip-prinsip objektifitas (maudlu'iyah),bukannya melulu sebuah kehendak Tuhan yang bersifat zatiyah. Sedangkan al Maqashid dibagi menjadi maqashid al syari' yang berarti wahyu dalam artian maksud Tuhan yang ditujukan kepada manusia yang didasarkan pada asas-asas objektifitas, yaitu dalam rangka mempertahankan kemaslahatan manusia dan maqashid al mukallaf yang berarti proses perubahan maksud yang suci ini menjadi maksud manusia.

Pemaparan Hasan Hanafi diatas memberi tahu kepada kita bahwa pelaksanaan hukum syara' sesungguhnya melalui proses yang gradual untuk sampai pada pelaksanaan secara praxis. Pada konteks al abkam, hukum wadl'iy adalah hukum dalam artian tekstual dan hukum taklify adalah hukum dalam pelaksanan manusia. Sedangkan dalam al maqashid, ada yang merupakan maksud Tuhan tentang hukum-hukum tertentu, yaitu dalam rangka menjaga kemaslahatan manusia. Namun maksud Tuhan tersebut masih bersifat normatif jika tanpa niat dan perbuatan manusia itu sendiri. Niat dan perbuatan manusia itulah yang dinamakan sebagai maqashid al mukallaf.

Elaborasi Hasan Hanafi yang sangat intens tentang revitalisasi Ilmu Ushul Fiqh diatas memberi tahu kepada kita bahwa "grand design" yang menjadi titik tolak dari proyeknya tersebut adalah sebuah pengalihan dan "pelampauan" dari Ushul Fiqh yang berparadigmaa tekstual-deduktif-bayani menjadi Ushul Fiqh yang berparadigma kontekstual-burhani-positivistik-eksperimental. ${ }^{62}$ Bagi Hasan Hanafi, pembaharuan dan "pelampauan" paradigma deduktif (min al nash ila

\footnotetext{
${ }^{61}$ Pembagian empat yang dimaksud adalah al hakim, al mabkum fih, al mabkum alaih dan al bukm.

${ }^{62}$ Lihat Hasan Hanafi, al Islam wa Tahadiyyat al 'Ashr, Jurnal Jauhar, Vol. II, No, 1, Juni,2001, h. 172. Dalam konteks inilah Hasan Hanafi memasukkan Ilmu ini sebagai golongan ilmu aqliyahnaqliyah, yang mempunyai objek kajian nash dan realitas. Selanjutnya baca Hasan Hanafi, Muqaddimah fiTlm al Istighrab, Terj " Oksidentalisme: Sikap Kita Terhadap barat”, (Jakarta: Paramadina, 2000), h. 1-2
} 
al waqi': mubawalah li'iadah bina'ilm Ushul Fiqh) ${ }^{63}$ ini bukannya tanpa sandaran historis dan teologis, namun Hasan Hanafi menyandarkannya secara genealogis kepada Ulama Ushul terdahulu seperti Imam Syatibi, Imam Syafi'I bahkan kepada Umar Bin Khattab.

Pemikiran Ushul Fiqh Hasan Hanafi tidak bisa kita nafikan dari bagaimana posisi dan responnya terhadap pemikiran Imam Syafi'i. Menurutnya Imam Syafi'I adalah imam yang ketiga yang berusaha menggabungkan antara pemikiran fiqh Imam Malaik di Hijaz dan fiqh Abu Hanifah di Irak. Antara 1 maslahah mursalah dan qiyas, antara tuntutan realitas dan metode istidlal dengan akal. Moderatisme $^{64}$ Syafi'I berarti sebuah usaha pembangunan pemikiran secara menyeluruh dan meliputi dan sebuah moderatisme historis yang berlandaskan pada penyingkapan realitas historis dan kemudian menganalisanya. Syafi'I tidaklah mengambil posisi yang mendamaikan antara Hadis dan Qiyas. Namun berusaha menggabungkan antara nash dan realitas. Moderatisme Syafi'I dengan demikian tidaklah diadasarkan pada ideologi, madzhab atau politik, namun berdasar dan berakar pada logika mantik.

Demikian juga tentang Arabisme Syafi'I, Hasan Hanafi meneguhkan bahwa Syafi'I bukanlah seorang yang Arab sentris dalam artian mempunyai ideologi Arab. Ia memang mencanangkan akan pentingnya bahasa Arab dalam analisa dan istimbath Ushul Fiqh, namun itu bukan berarti bahwa ia terjebak pada ideologi dan sentimen kearaban ('urubah). Alqur'an dan Hadis diturunkan dalam bahasa dan budaya Arab, maka tidak berlebihan jika penguasaan bahasa Arab menjadi salah satu entitas penting dalam istinbat hukum, lebih dari itu bukankah pengetahuan tentang bahasa Arab dan asbab al nuzul juga menjadi syarat bagi setiap mufassir, bukan hanya ia saja. ${ }^{65}$

${ }^{63}$ Baca juga Hasan Hanafi, Mawqifuna min al Turas al Qadim, (Kairo : al Markaz al Araby, 1980), h. 213-6 dalam Ainurrofiq, Ibid

${ }^{64}$ Statemen Hasan Hanafi ini merupakan respon dan tanggapan balik terhadap apa yang diungkapkan oleh Nashr Abu Zaid dalam salah satu bukunya yang mengatakan bahwa Imam Syafi'I adalah seorang faqih yang gagasangagasannya dipengaruhi oleh ideologi moderatisme, Arabisme dan literalisme. Selanjutnya baca Hasan Hanafi, Huwar al Ajyal, (Kairo, Dar Quba' li al Thiba'ah wa al Nasyr wa al Tauzi'), h. 447-469

${ }^{65}$ Hasan Hanafi, Op.Cit, h. 448 
Beberapa komentarnya tentang pemikiran Imam Syafi'I akhirnya menunjukkan bahwa Hasan Hanafi adalah orang yang meneguhkan pemikiran syafi'i sebagai genealogy pemikiran Ushul Fiqh. Syafi'I, menurutnya adalah orang yang mempunyai komitmen mendalam terhadap istinbat hukum syari'ah dan menjadi bapak (founding father) dari lahirnya Ilmu Ushul Figh. ${ }^{66}$

Jika kita melacak lebih jauh dan mendalam sesungguhnyaa akar dari dari pemikiran revitalisasi Ilmu Ushul Fiqh Hasan Hanafi adalah proyek besarnya yang sangat masyhur yaitu "al Turas wa al Tajdid". Nuansa kembali kepada tradisi dan khazanah klasik Ushul Fiqh serta konsep-konsep yang dibangun oleh ulama Ushul Fiqh terdahulu menjadi titik tolak bagi Hasan Hanafi dalam melakukan pembaharuan metodologi Ushul Fiqh, namun pada saat yang sama konsep-konsep tersebut difahami secara progresif sesuai kondisi saat ini.

\section{E. Pendekatan Historis Sebagai Metode Revitalisasi Ilmu}

\section{Ushul Fiqh.}

Sudah menjadi pemahaman bahwa salah satu concern Hasan Hanafi adalah usahanya untuk melakukan revitalisasi terhadap khazanah klasik keislaman, ${ }^{67}$ salah satunya adalah tentang revitalisasi Ilmu Ushul Fiqh, karena menurutnya dalam Ilmu Ushul Fiqh terdapat beberapa konsep dan gagasan yang sangat relevan sebagai basis dan sandaran untuk melakukan rekonstruksi pemikiran Ushul Fiqh. Sebuah konsep yang merupakan respon para ushuliyun terhadap problematika Fiqh yang ada pada masa dahulu. "Sejarah"68 dan "manusia" menjadi kata kunci yang sangat penting digunakan oleh

${ }^{66}$ Tentang penyandaran revitalisasi metodologi Ushul Figh Hasan Hanafi terhadap Imam Syafi'I dapat dibaca dalam karyannya Huwar al ajyal, op cit, h. 448460

${ }^{67}$ Lihat Kazou Shimogaki, Between Modernity and Postmodernity : The Islamic Left and Dr. Hasan Hanafi's Thought, Terj M. Imam Aziz dan Jadul Maula ,'Kiri Islam : Antara Modernisme danPostmodernisme ; Telaah Kritis Pemikiran Hasan Hanafi”, (Yogyakarta: LKIS, Cet IV, 2000), h. 92.

${ }^{68}$ Tentang signifikansi sejarah dalam proses revitalisasi Imu Ushul Fiqh dapat dibaca dalam Hasan Hanafi, Dirasat....., Op. Cit., h. 439-442

${ }^{69}$ Adapun tentang pentingnya pembahasan manusia dalam usaha revitalisasi Ilmu Ushul Fiqh dapat dibaca dalam Hasan Hanafi, Ibid, h. 407-411 
Hasan Hanafi dalam melakukan usaha revitalisasi terhadap Ilmu Ushul Fiqh.

Ilmu Ushul Fiqh menurut Hasan Hanafi adalah ilmu yang banyak membahas tentang "manusia", ini berbeda dengan ilmu-ilmu teoritis yang lain seperti Ilmu Ushuluddin dan Filsafat, karena ilmu ini adalah ilmu praktis. Namun dalam sejarahnya masih banyak kekurangan dalam ilmu ini, yaitu kekurangan dalam pentaqninan dan dalam konsep amar dan nawahy. Dalam Ilmu Fiqh dapat kita temui bahwa semua pembahasannya memfokuskan pada kehidupan manusia. Baik kehidupan manusia secara individual atau kehidupan manusia bersama keluarganya, masyarakat dan dengan Tuhan.

Sehingga dengan demikian Fiqh merupakan sifat yang meletakkan manusia dalam ilmu, demikian juga dalam Ilmu Ushul Fiqh yang membahas dan bertujuan melakukan istimbath terhadap

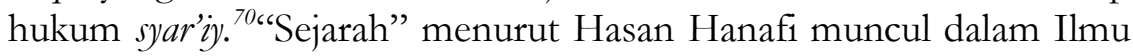
Ushul Fiqh, yaitu ilmu yang menjadikan wahyu sebagai sesuatu yang sinergis dan selaras secara terus menerus dengan berbagai fase sejarah dan keadaan masyarakat dan berbagai zaman dan waktu. Namun karena kesalahan dalam memahami sejarah, walaupun ia muncul dalam pentasyri'an, jurisprudensi dan hukum, kemudian hilanglah kekuatan, titik tolak dan gerakannya. ${ }^{71}$

a. Revitalisasi Terhadap Al-Adillah Al-Syar'iyyah.

Menurut Hasan Hanafi, para ulama Ushul Fiqh telah memfokuskan diri pada pembahasan al adillah al syar'iyyah al arba'ah, Kitab, Sunnah, Ijma' dan Qiyas setelah mereka menolak syar'u man qablana sebagai sumber hukum. Ini mengakibatkan keterputusannya dengan syari'at-syari'at terdahulu dan pengetahuan tentang syari'ah serta bagaimana memahami sejarah dan aturan umat-umat terdahulu padahal masalah itu merupakan asas pokok dari sejarah. Adapun persoalan pembangunan syari'ah dalam masyarakat tidak bisa dipisahkan dengan sejarah karena pembangunan ilmu kemasyarakatan harus didahului dengan pembangunan ilmu sejarah. ${ }^{72}$

${ }^{70}$ Ibid, h. 407

${ }^{71}$ Ibid,

${ }^{72}$ Lihat dalam Tulisan Hasan Hanafi, Manahij al Tafsir fi Ilm Ushul Fiqh, (Kairo, Cetakan Amerika, 1965), ( dengan bahasa perancis) dalam Hasan Hanafi, Ibid, h. 439 
Sehingga dengan demikian bagi Hasan Hanafi adalah sangat mungkin bahwa al adillah al arba'ah merupakan teori tentang perkembangan sejarah dimulai dari wahyu sebagai proses ijtihad kemanusiaan paling utama pada masa Nabi, kemudian Sunnah yaitu perkataan, perbuatan dan ketatapan Nabi sebagai realisasi kedua dalam sejarah, kemudian ijma' (kesepakatan) umat sebagai realisasi yang ketiga dalam sejarah dan ijtihad umat Islam sebagai realisasi yang keempat. Sehingga keempat adillah ini merupakan realisasi wahyu dalam sejarah. Dari Allah kepada kesadaran Nabi, kemudian kepada kesadaran umat dan akhirnya kepada kesadaran individual. Sehingga pada akhirnya keempat sumber hukum ini mempunyai relasi top-down (tanazuliyah), yaitu dari nash menuju realitas. ${ }^{73}$

Menurut Hasan Hanafi, hilangnya dimensi sejarah dalam adillah syariyah terjadi tatkala ada distorsi dalam proses ini. Pada awalnya adillah syariyah bermakna keempat fase untuk merealisasi wahyu ke dalam sejarah (al marabil alarba' fi tahqiq al wahy fi al tarikh), namun kemudian berubah menjadi sumbersumber tasyri' (mashadir al tasyri')yaitu kitab, riwayat, ijma' dan peran fatwa.

Kemudian hilanglah gerakan sejarah dan peran akal dalam memahami hukumhukumnya. Dalam konteks ini Hasan Hanafi menggagas untuk merubah urutan aladillah al arba'ah menjadi dimulai dari ijtihad atau realitas kehidupan manusia, kemudian dengan umat atau jama'ah sebagai entitas yang lebih besar kemudian dengan mencari petunjuk dengan Sunah dan terakhir denga meruju' kepada yang serba meliputi, yaitu al Qur'an. Dengan demikian maka ilmu sejarah di kembangkan menjadi ilmu induktif. ${ }^{74}$

Hasan Hanafi berpegang teguh bahwa dalam al adillah al syari'yyah yaitu al Qur'an dan Sunnah sesungguhnya telah muncul dimensi manusia. Dalam proses tranmisi Hadis misalnya seorang rawy menjadi perhatian utama ulama Ushul pada masa dahulu. Artinya bahwa manusia menjadi faktor utama proses istinbat. ${ }^{75}$ Selanjutnya, bahwa proses perpindahanan al mashadir al arba'ah yaitu alQur'an, Sunnah, Ijma' dan Qiyas sesungguhnya merupakan proses usaha

${ }^{73}$ Hasan Hanafi, Humum al Fiker wa al Wathan al Araby,(Dar Quba' li al Thiba'ah wa alNasyr,1998), h. 387

${ }^{74}$ Hasan Hanafi, Dirasat...., Op.Cit , h. 440

${ }^{75}$ Selanjutnya baca Ibid, h. 408 
(ijtihad) manusia dalam konteks syari'ah. Kitab merupakan kumpulan dari kejadian yang terjadi pada Islam terdahulu yang memberi solusi terhadap persoalan pada waktu itu. Dan setiap kejadian merupakan sebuah permisalan yang sangat mungkin untuk terulang lagi pada setiap waktu dan tempat. Dan jika kejadian yang serupa terjadi kembali, maka kita dapat mengambil solusi yang serupa. Ini merupakan keistimewaan wahyu Islam yang tidak dimiliki oleh umat lain. Dalam ilmu al Qur'an hal ini biasa disebut sebagai "al tanjim" dalam ilmu tafsir disebut sebagai "ilmu asbab al nu₹ul".

Para Ushuliyun menamakan permisalan ini sebagai "al manath", yaitu kejadian manusia yang hidup. ${ }^{76}$ Selain itu, menurutnya persoalan yang menyita perhatian para ulama terdahulu adalah masalah nask $h$. Naskh secara bahasa berarti pembatalan atau penghilangan.

Adapun secara istilah adalah firman Allah (kbitab) yang menunjukkan atas penghapusan hukum yang ada dengan hukum yang kemudian. Naskh mempunyai beberapa rukun, yaitu naskh, nasikh, mansukh dan mansukh minhu. Pada hakekatnya bahwa naskh dalam al Qur'an menunjukkan atas adanya wahyu dalam zaman dan menunjukkan akan perubahan wahyu sesuai keberadaan, kemampuan dan thabiatnya yang mana terdapat dinamika di dalam individu dan masyarakat dalam sejarah.

Sehingga dengan demikian wahyu tidaklah keluar dari sejarah, tetap, tidak berubah tetapi berada dalam zaman yang terus berkembang. Bukanlah tujuan wahyu hanya untuk menggambarkan sebagaimana syi'ir yang tanpa realisasi dalam zaman, namun wahyu bertujuan melaksanakan dalam sejarah sesuai kemampuan pribadi dan individu. $^{77}$

Dalam hal inilah, menurut Hasan Hanafi, al Qur'an beserta teks-teksnya merupakan produk sejarah yang keberadaannya dipengaruhi oleh lingkungan dan setting sosio-kultural. Konsep asbab al nuгul dan nasikh mansukh mengindikasikan bahwa wahyu dan hukum Allah turun dalam sejarah dan ruang kemanusiaan tertentu. Maka dengan demikian, penetapan hukum dan istimbat hukum harus memperhatikan realitas kemanusiaan setempat.

\footnotetext{
${ }^{76} \mathrm{Ibid}$,

${ }^{77} \mathrm{Ibid}$, h. 81
} 
Sedangkan Sunnah merupakan kumpulan kejadian yang terperinci yang dibatasi hanya berupa perbuatan manusia. Sunnah juga merupakan perbuatan yang menjadi permisalan bagi manusia dan proses usaha manusia yang harus ditiru yang mana kita dapat melaksanakannya, namun tentu saja terbatas pada kejadian-kejadian tertentu. $^{78}$

Maka Sunnah dalam artian substansi teksnya harus difahami dalam perspektif historis juga. Dengan demikian metode asbab al wurud menjadi salah satu pertimbangan untuk melakukan istimbat.

Menurut Hasan Hanafi, Sunnah tidak akan ada tanpa terlebih dahulu melakukan realisasi pertama dalam masyarakat dan setelah terjadi proses penafsiran pada masa tertentu, yaitu dalam ijtihad atau arahan (tanjib), ${ }^{79}$ kemudian baru muncul gerakan baru dalam sejarah, namun para Ushuliyun menafikan proses ini dan kemudian menjadikan metode riwayah dalam hadis sebagai pedoman. Mereka juga memisahkan antara mutawatir dan syarat-syaratnya serta ahad dan syarat-syaratnya sebagai syarat bagi sanad, seperti juga menafikan naql bi al ma'na dan wadl' bi al ma'na sebagai metode memahami matan, maka terjadilah perubahan dari sejarah politik menjadi sejarah periwayatan terhadap teks verbal. ${ }^{80}$ Maka Sunnah bagi Hasan Hanafi, telah mengalami sebuah proses evolusi historis yang sangat complicated. Proses sejarah yang terjadi dalam Sunah harus benar-benar difahami, baik dalam sanad maupun matan, hanya dengan begitu proses istimbat dapat berjalan dengan baik.

Sebagaimana telah disebutkan diatas bahwa Hasan Hanafi telah merevitalisasi makna Ijma' secara lebih kontekstual, progresif dan rasional. Perspektif kemanusiaan dan kesejarahan menjadi satu entitas yang integral dalam konsep Ijma' . Maka bagi Hasan Hanafi, Ijma' merupakan proses usaha dan akumulasi dari sebuah generasi yang merupakan unsur dari sejarah. Adapun setiap persoalan bersama

\section{${ }^{78}$ Ibid}

${ }^{79}$ Bandingkan dengan konsep yang dipakai oleh Fazlur rahman dalam memaknai relasi historis antara Sunnah- Ijtihad dan Ijma', Selanjutnya baca Fazlur Rahman, Islamic Methodology in History, (Karachi:Central Institue of Islamic Research, 1965), h. 74

\footnotetext{
${ }^{80}$ Hasan Hanafi, Dirasat... Op.Cit,. h. 441
} 
dan segala proses sejarah merupakan kebalikan dari sebuah nafsu individual dan kejumudan aqidah. ${ }^{81}$

Adapun ijtihad (baca:Qiyas) bertujuan untuk menjaga kemaslahatan umum dan membangun sebuah hukum sesuai kebutuhan manusia, apa yang menurut manusia baik, maka menurut Allah juga baik. Ini menujukkan bahwa "manusia" benar-benar ada dalam adillah syar'iyyah (baca :Qiyas). ${ }^{82}$ Selain itu Penggolongan Hasan Hanafi terhadap Ijma' dan Qiyas sebagai wahyu yang hidup (waby hay), setelah ia mendefinisikan al Qur'an dan Sunnah sebagai wahyu tertulis (maktub) ${ }^{83}$ adalah indikasi akan keterlibatan manusia dan sejarah dalam proses kedua sumber hukum Islam ini. Selain itu bahwa Qiyas dan Ijma' mempunyai peran yang besar dalam istinbat syara' karena mewujud dan selalu ada dalam sejarah.

b. Revitalisasi Terhadap Thuruq Al-Istinbat.

Thuruq al Istinbat secara bahasa berarti metode untuk melakukan istimbath (pengeluaran hukum). Hasan Hanafi memahami terminologi ini identik dengan al syu'ur al ta'ammuly (kesadaran reflektif), yaitu pembahasan tentang lafaz, makna dan'illah yang mana mempunyai signifikansi untuk memahami nash-nash danmenafsirkannya. ${ }^{84}$

Dalam thuruq al istinbat dimensi manusia dapat kita temui dalam hal bahasa.Bahasa merupakan entitas murni kemanusiaan. Manusia merupakan satu-satunyamakhluk yang berbicara dengan bahasa dan mendengarkan kata-kata. Muncullahentitas perasaan (a'maq) yang berbeda dalam memahami makna dzabir dan mu'awwal. Demikian juga terdapat entitas "pemalingan" atau "pentarjihan" dalam mubkam dan mutasyabih. Terdapat entitas individu dalam 'am dan khash. Terdapatentitas perbuatan dalam amr dan nawaby demikian juga dalam persoalan yang lainseperti dalam siyaq, dilalah yang menunjukkan pada makna dan beberapa persoalanyang berkaitan dengan bahasa dalam memahami Ushul Fiqh. ${ }^{85}$
${ }^{81}$ Ibid
${ }^{82}$ Ibid, h.408
${ }^{83}$ Ibid, h.73
${ }^{84}$ Ibid, h. 78
${ }^{85} \mathrm{Ibid}$, h. 409 
Dalam persoalan mujmal-mubayyan Hasan Hanafi menegaskan bahwa kedua halini mengisyaratkan akan usaha manusia untuk memilih diantara dua makna yangsesuai dengan kondisi dan kemaslahatan manusia. Demikian juga dalam hal dzabir dan mu'awwal, 'am-khash dan amr-nawaby kesemuanya menunjukkan akanpentingnya dimensi sejarah dalam nash-nash syar'iyah dan untuk merubah nashnash syariyyah ke dalam sejarah. ${ }^{86}$

Ta'wil misalnya dimaknainy sebagai usaha dalam rangka merealisasi nash-nashwahyu sesuai kondisi dan kebutuhan umat dan menolak pemaknaan literal menujukemaslatan umat. Amr dan nawaby menunjukkan adanya entitas perbuatan dalamsejarah dan bahwa wahyu merupakan firman yang harus direalisasikan. Adapun 'am dan khash menujukkan bahwa hukum diperuntukkan kepada individu dan kolektiv,adapun tujuannya adalah untuk memberi arahan perilaku manusia, baik individu ataukolektif dan merubahnya dalam sejarah. ${ }^{87}$ Ini artinya sejarah menjadi entitas pentingdalam thuruq al istimbath untuk kepentingan pengembilan sebuah hukum. sejarahdengan sendirinya menjadi bagian yang tidak terpisahkan dari sebuah proses refleksidan kontemplasi terhadap dalil-dalil dan nash-nash syara'. Maka pendekatankesejarahan dalam thuruq al istinbat menjadi sebuah keharusan bagi Hasan Hanafi.

c. Revitalisasi Terhadap Al-Ahkam Al-Syar'iyyah

Menurut Hasan Hanafi, dalam abkam syariyah dapat kita temui banyak sekali entitas manusia di dalamnya. Dalam maqashid misalnya yang terdiri dari maqashidal mukallaf dan maqashid al syari'. Maqashid al mukallaf bertujuan untuk melindungi terhadap kebutuhan pokok manusia yaitu hidup, agama, akal, keturunan dan kehormatan Harta merupakan entitas-entitas kemanusiaan, karena hidup adalah hidup manusia, demikian juga akal, keturunan, kehormatan dan Agama. Semuanya disandarkan kepada manusia. ${ }^{88}$

\footnotetext{
${ }^{86} \mathrm{Ibid}$, h. $79-86$

${ }^{87}$ Ibid

${ }^{88}$ Ibid, h. 99
} 
Sedangkan dalam maqashid al syari' yang terdiri dari empat macam. ${ }^{89}$ Pertama adalah wadl al syari'ah ibtida'an, yaitu sebab pertama yang untuknya syari'ah ditujukan, yaitu dalam rangka menjaga kemaslahatan seorang hamba, sekarang atau nanti, ${ }^{90}$ maka dimensi manusia menjadi prioritas utama dan fokus dari tujuan pentasyri'an, manusia adalah obyek dari segala pentasyri'an. Kedua wadl al syariabli al taklif, yaitu bahwa syari'ah tidak akan dibebankan terhadap seseorang yang tidak mampu untuk melaksanakannya dan pelaksanannya di sesuaikan dengan kemampuan seseorang, sehingga dengan demikian al qudrah (kemampuan) merupakan syarat pembebanan. Pembebanan,dengan demikian di dihalangi oleh masyaqqah.Masyaqqah ada empat, yaitu masyaqqah berupa ketidakmampuan. Masyaqqah ini menghalangi pembebanan. Masyaqqah dari luar, ini juga menghalangi pembebanan. Masyaqqah yang berupa tambahan atas apa yang telah ada, ini tidak menghalangi pembebanan. Dan yang terakhir adalah masyaqqah yang bertentangan dengan hawa.

Ini adalah yang dimaksud dengan dengan taklif. ${ }^{11}$ Pembebanan dengan demikian berkaitan erat dengan kemampuan manusia itu sendiri. Jika manusia terkena masyaqqah maka tidak ada hukum baginya. Manusia dengan demikian menjadi obyek utama syari'ah. Ketiga wadl al syariah li al afham, yaitu difahami dan sampainya syari'ah kepada akal sehingga masuk dan ditela'ah secara mendalam dan terekspresikan dalam karakter mukallaf, bukan hanya sesuatu yang diluar, sehingga sempurna dalam melaksanakannya dalam rangka mentaati syari. ${ }^{92}$ Pemahaman tentu saja berkait erat dengan kapan dan dimana pemahaman itu terjadi, ia tidak bisa di pisahkan dari konteks historis terjadinya sebuah pemahaman. Sejarah menjadi faktor dari proses pemahaman seseorang terhadap firman Tuhan. dan Keempat wadl alsyariah li al imtitsal.yaitu mengeluarkan mukallaf dari dimensi hawa nafsu kepada dimensi wujud yang objektif dan tetap. ${ }^{93}$ Dimensi wujud merupakan manifestasi dari kesadaran seseorang

89 Pembagian abkam menjadi abkam dan maqashid serta pembagian maqashid menjadi empat ini diadopsi oleh Hasan Hanafi dari pembagian yang dilakukan oleh Imam al Syathibi.

${ }^{90}$ Ibid,

${ }^{91}$ Ibid

${ }^{92}$ Ibid

${ }^{93}$ Selanjutnya baca Ibid, h. 99-102 
terhadap sejarahnya (al wayu bi al tarikh), sehingga kesadaran terhadap sejarah menjadi hal yang mutlak dari proses pelaksanaan syari'ah.

Dalam al abkam yang terdiri dari abkam wadl'y dan abkam taklify yang mana hukum wadliy bertujuan membangun hukum yang objektif di alam sebelum direalisasi oleh manusia, dapat difahami kadang-kadang berwujud hal yang bersifat normatif (mitsaly) seperti arimah atau berwujud sesuatu yang bersifat implementatif seperti rukhshah. Perbuatan manusia dengan demikian bukanlah hanya terdapat di awal pelaksanaan hukum, namun ia merupakan bangunan perbuatan yang menyeluruh yang dimulai dari sebelum, beserta dan sesudah perbuatan. Kemampuan adalah sebelum perbuatan, niat beserta dengan perbuatan dan konsistensi adalah setelah perbuatan. ${ }^{94}$

Sedangkan dalam hukum taklifi, substansinya adalah dalam rangka menjaga manusia terhadap perbuatannya. Yaitu terdiri dari melaksanakan perbuatan sebagai kewajiban, keharaman, kemubahan, kemakruhan dan kesunahan. Tentu saja kelima hukum ini bukan bertujuan untuk hanya membebani manusia, namun harus difahami sebagai sarana memanusiakan manusia. ${ }^{95}$ Dalam hal ini bagi Hasan Hanafi, hukum wajib harus difahami sebagai sebuah pilar yang mengafirmasi kehidupan seseorang.

Haram harus difahami sebagai sesuatu yang merusak kehidupan. Mandub harus ditafsirkan sebagai kebolehan untuk melakukan sesuatu yang baik secara sukalera dan sesuai kapasitas manusia. Makrub sebagai sebuah peringatan untuk menghindari secara sukalera mengerjakan sesuatu yang membuat rusaknya kehidupan seseorang. Serta Halal sebagai sebuah kebolehan untuk melaksanakan sesuatu yang tidak berbahaya bagi sesorang. ${ }^{96}$ Sehingga dengan demikian dimensi manusia adalah locus utama dari pembagian Ushul Fiqh menjadi lima hukum ini. Tujuannya adalah manusia bukan pembebanan itu sendiri.

${ }^{94}$ Ibid, h. 100

${ }^{95}$ Hasan Hanafi, al Turas wa al Tajdid, Op.Cit,h. 166-167 dalam Yudian Wahyudi, The Slogan Back to Qur'an and Sunah: a Comparative Study of the Responses of Hasan Hanafi., M. Abid Al Jabiry and Nurcholis Madjid, (Montreal: The Institute of Islamic Studies, 2002),h. 175

${ }^{96}$ Ibid 
Secara makro jika al abkam al syar'yah difahami sebagai sesuatu yang merupakan produk (tsamrah) ${ }^{97}$ dari proses istimbath hukum, maka ia bersentuhan langsung dengan waktu dan tempat terciptanya produk hukum tersebut, sehingga pelaksanaannya tentu mepertimbangkan locus dan tempus serta tantangan sejarah yang mengitarinya. Sedangkan bila al abkam al syariah difahami sebagai kbithabsyar'iy (firman Tuhan), maka ia merupakan produk dari sejarah pada saat munculnya teks firman Tuhan tersebut. Maka dengan demikian sejarah menjadi sesuatu yang melekat dan bersentuhan secara langsung dengan al abkam al syar'iyah.

\section{F. Penutup}

Demikian pengkajian dan penelitian pemikiran Ushul Fiqh Hasan Hanafi berkaitan dengan usahanya tentang revitalisasi Ilmu Ushul Fiqh dengan pendekatan historis . Dari hasil penelitian ini dapat diambil kesimpulan bahwa :

1. Hasan Hanafi adalah tokoh yang sangat concern terhadap upaya mengidupkan kembali ruh dan spirit (revitalisasi) Ilmu Ushul Fiqh dengan menggunakan pendekatan historis. Menurutnya dimensi sejarah dan manusia menjadi faktor yang penting dalam rangka mendekati konsepsi-konsepsi dan metodologi Ushul Fiqh. Sebenarnya dimensi sejarah dan manusia tersebut terdapat dalam metodologi Ushul Fiqh yang baku namun dimensi sejarah ini lama-lama "punah" dan terlepas dari Ushul Fiqh ketika proses pembangunan Ilmu ini berlangsung dan mewujud dalam proses perkembangan ilmu ini. Sehingga sesungguhnya menurut Hasan Hanafi, dimensi sejarah pada hakekatnya mewujud dalam seluruh unsur Ushul Fiqh, yaitu dalam 'adillah syar'iyah, thuruq al istinbat dan al abkam al syariiyah. Dimensi sejarah ini direpresentasikan oleh Hasan Hanafi dengan kedua kata kunci, yaitu "sejarah" dan "manusia"

2. Hasan Hanafi adalah orang yang peduli terhadap keberadaan Ilmu Ushul Fiqh, dalam rangka itu dia mengatakan akan pentingnya upaya revitalisasi metodologi Ushul Fiqh.

${ }^{97}$ Lihat Ibid, h. 68 
Revitalisasi dalam pemikiran Hasan Hanafi adalah upaya melakukan pembaharuan dan penyesuaian terhadap metodologi Ushul Fiqh berdasar kondisi setting sosial dan realitas kemanusiaan serta ilmu-ilmu yang berkembang, namun usaha ini bertitik tolak pada tradisi dan khazanah metodologi Ushul Fiqh yang dibangun oleh ulama terdahulu. Dengan usaha demikian maka diharapkan pembaharuan metodologi Ushul Fiqh pada satu sisi dapat memecahkan problem hukum kontemporer yang semakin complicated, namun pada sisi yang lain tidak tercerabut dari akar dan genealogi metodologi Ushul Fiqh.

3. Bahwa pemikiran Ushul Fiqh Hasan Hanafi sangat relevan terhadap upaya reaktualisasi hukum Islam. Hal ini dikarenakan terjadi sebuah "kejumudan" yang mendalam dalam pemikiran Ushul Fiqh sehingga dalam realitas yang sebenarnya Ilmu Ushul Fiqh telah terjadi proses pembekuan. Signifikansi pemikiran Ushul Fiqh Hasan Hanafi terletak pada upaya memghidupkan kembali spirit dan elan vital Ilmu ini dengan meggunakan pendekatan historis. Yaitu bahwa bahwa dimensi manusia dan sejarah menjadi satu hal yang harus dilibatkan dalam proses istimbath hukum.

4. Pemikiran historis Ushul Fiqh Hasan Hanafi yang tercover dalam dimensi manusia dan sejarah sesungguhnya mempunyai akar dari pemikiran dan proyek Hasan Hanafi tentang al Turas wa al Tajdid (Tradisi dan Pembaharuan). Karena hilangnya dimensi manusia dan sejarah dalam tradisi dan khazanah pemikiran umat Islam merupakan persoalan pokok yang menjadi sebab dari tidak nihilnya progresifitas dalam tradisi dan tindakan umat Islam. 


\section{Daftar Pustaka}

A.H. Ridwan, Reformasi Intelektual Islam : Pemikiran Hasan Hanafi tentang Reaktualisasi Tradisi Keislaman, (Jakarta Ittiqa Press).

Abdul Hamid Uways, al Figh al Islamy Bayna al Tathawnur wa Al Tsabat,Terj A.Zarkasy Chumaidy, 'Fiqh Dinamis- Fiqh Statis",(Bandung : Pustaka Hidayah 1998)

Abdurrahman Wahid dalam pengantar Kazuo Shimogaki, Between Modernity and Postmodernity : The Islamic Left and Dr. Hasan Hanafi's Thought, Terj M. Imam Aziz dan JadulMaula , "Kiri Islam : Antara modernisme dan Postmodernisme ; Telaah Kritis pemikiran HasanHanafi”, (Yogyakarta: LKIS, Cet IV, 2000)

Ahmad Hasan, The Early Development of Islamic Jurisprudence, (Karachi :

Kitab Bavan, 1989)

Ainurrofiq, Menawarkan Epistemologi Jama'I Sebagai Epistemologi Ushul Fiqh: Sebuah: Tinjanan Filosofis dalam "Mazhab Jogja: Membangun Paradigma Ushul Fiqh Kontemporer",(Yogyakarta: Arruz, 2004)

Azumardi Azra, Islam Reformis: Dinamika Intelektual danGerakan, (Jakarta, Rajawali Press, 1999)

Fazlur Rahman, Islamic Methodology in History, (Karachi:Central Institue of Islamic Research, 1965)

Hasan al Turaby, Tajdid al Fiker al Islamy, Ter Abd. Kharis dan Za'im Am, "Fiqh Demokratis : Dari Tardisionalisme Kolektif Menuju Modernisme Populis", (Arasy, Cet I, 2003)

Hasan Hanafi, al Din wa al Tsaqafah wa al Siyasah fi al Wathan al'Araby,Kairo: Dar Quba' li al Thiba'ah wa al Nasyr, 1997 , al Islam wa Tahadiyyat al 'Ashr, (Jurnal Jauhar, Vol. II, No, 1, Juni, 2001) 
, al Ushulyyah al Islamiyah dalam al Din wa al Tasaurah, fi Mishr, Terj Kamran As'ad, "Aku Bagian dari Fundamentalisme islam", (Yogyakarta, Studi Islamika), 2003

, Dirasat Islamiyah, Kairo :Maktabah Anglo Mishriyah,1987

- Humum al Fiker wa al Wathan al Araby, (Dar Quba' li al Thiba'ah wa al Nasyr,1998)

- Huwar al Ajjal, Kairo; Dar Quba' Li al Thiba'ah wa al tauzi', 1980

, Mawqifuna min al Turas al Qadim, (Kairo : al Markaz al Araby, 1980)

, Min al Naql ila al ibda', (Dar Quba' wa Nasyr wa al Yauzi', 1990)

, Muqaddimah fiTlm al Istighrab, Terj "Oksidentalisme: Sikap Kita Terbadap barat”, (Jakarta: Paramadina, 2000)

Ibnu Khaldun, Tarikh Ibnu Khaldun, (Beirut: Dar al Kutub al 'Ilmiyah, Jilid I, Cet I, 1998)

Ilham B, Saenong, Hermeneutika Pembebasan: Metodologi Tafsir Alqur'an Menurut Hasan Hanafi, (Bandung : Teraju, 2002)

Imam Syafi'I, Ar-Rrisalah, Terj: Ahmadie Thoha, (Jakarta, Cet IV, 1996)

Joseph Schacht, An Intoduction to Islamic Law, (London : Oxford At The Clarendon Press, 1971)

Kazou Shimogaki, Between Modernity and Postmodernity : The Islamic Left and Dr. Hasan Hanafi's Thought, Terj M. Imam Aziz dan Jadul Maula,"Kiri Islam: Antara Modernisme danPostmodernisme; Telaah Kritis Pemikiran Hasan Hanafi”, (Yogyakarta: LKIS, Cet IV, 2000)

M. Abid al Jabiry, Islamic Methodology in History, (Karachi :Central Institue of Islamic Research, 1965)

M. Abid al Jabiry,Tarikbiyyah al Fiker al Araby al Islamy, (Lebanon, Mansyarat Markaz al Inma' al Qaumy, Cet I, 1896) 
M. Amin Abdullah, Paradigma Alternatif Pengembangan Ushul Figh dan Dampaknya pada Figh Kontemporer dalam "Madzhab Jogja : Membangun Ilmu Ushul FiqhBerparadigma Kontemporer", Ainurrofiq (ed), (Yogyakarta : Arruz, 2003)

M. Aunul Abied Syah (Ed), Islam Garda Depan : Mosaik Pemikiran Timur Tengah, M. Aunul Abied Syah (Ed), (Bandung: Mizan, 2001)

M.Abid Al Jabiry, Post Tradisionalisme Islam, terj Ahmad Baso, (Yogyakarta : LKIS, 2001)

M.K. Mas'ud, Syatbibi's Philosophy of Islamic Law,(Delhi:Adam Publishers and Distributors, 1997)

Mualim dan Yusdani, Konfigurasi Pemikiran Hukum Islam, (Yogyakarta, UII Press)

Muhamad Arkoun, Nalar Islam Dan Nalar Modern; Berbagai Tantangan dan Jalan Baru, (Jakarta : INIS, 1994, Cet I)

Nasrudin Ruli, Konsep Ijtihad as Syaukani :Relevansinya Bagi Pemabaharuan Hukum Islam di Indonesia, (Jakarta : Logos Wacana Ilmu, 1999)

Peter L. Salim, The Contemporary English-Indonesian Dictionary,, Jakarta:

Media English Press, ed 6, 1991)

Qordy Azizy, Eklektisisme Hukum :Kompetisi Antara Hukum Islam dan Hukum Umum, (Yogyakarta: Gama Media, 2002)

Wael B. Hallaq, A History of Islamic Legal Theories, Terj, E. Kusnadiningrat,dan Abd. Haris bin wahid, "Sejarah Teori Hukum Islam ”,(Jakarta: Rajawali Press, Cet II, 2001)

Yudian Wahyudi, The Slogan Back to Qur'an and Sunab: a Comparative Study of the Responses of Hasan Hanafi., M. Abid Al Jabiry and Nurcholis Madjid, (Montreal: The Institute of Islamic Studies, 2002) 
Badruzaman 